\title{
Chemical Archeoceanography
}

\author{
Francis Albarede ${ }^{a, b}$, Fanny Thibon ${ }^{a}$, Janne Blichert-Toft ${ }^{a, b, *},{ }^{*}$ and Harilaos Tsikos ${ }^{c}$
}

a Laboratoire de Géologie de Lyon, Ecole Normale Supérieure de Lyon, CNRS UMR 5276, Université de Lyon, 46 Allée d'Italie, 69007, Lyon, France

${ }^{\mathrm{b}}$ Department of Earth, Environmental and Planetary Sciences, Rice University, Houston TX 77025, U.S.A.

*Corresponding author: jblicher@ens-lyon.fr; +33608134849

Abstract

1. Introduction

2. The controls on ocean chemistry

2.1. The rise of continents and the changing runoff

2.2. Chemical sedimentation

2.3. The mid-ocean ridge hydrothermal systems

2.4. Low-temperature marine sources and sinks

3. Equilibria in Archean seawater

3.1. The charge balance

3.2. The proton balance and the chlorine question 3.3. The electron balance

4. Some pre-GOE geochemical cycles

4.1. Chlorine

4.2. Protons

4.3. Electrons

4.4. Iron

4.5. Sodium and potassium

4.6. Magnesium and calcium

4.7. Phosphorus

4.8. Alkalinity

5. Conclusions

Acknowledgements 
Plain language summary. We here evaluate the constraints on seawater chemistry before 20 free oxygen was introduced into the atmosphere some 2.4 billion years ago. We suggest a simple conceptual framework which we validated on modern seawater and which is based on two so-far largely overlooked observations, namely that the phosphorus concentration and strontium isotopic records in ancient sediments require that emerged continental land masses were covering only $7 \%$ of Earth's surface at the time of the Great Oxidation Event instead 25 of 30\% today. Atmospheric and seawater chemistry critically depend on this proportion as well as on the chlorinity of the ocean. The oxygen-free atmosphere allowed iron to remain in solution and to reduce atmospheric carbon dioxide to methane. The $\mathrm{pH}$ of the ancient oceans must have been lower because less river water was available to neutralize the acidic submarine high-temperature hydrothermal fluids emitted at mid-ocean ridges. Limited continental 30 surface starved the sedimentary column for clays. The low $\mathrm{pH}$ and scant phosphorus drainage led to rare carbonate deposition. We conclude by proposing a new scheme for Archean marine chemistry and geochemical cycles that can explain the chemical and geological observations from the Archean and early Proterozoic rock record.

Abstract. Elemental fluxes to the ocean are expected to increase with the surface area of con-

tinental exposure to weathering and atmospheric $P_{\mathrm{CO} 2}$. The record of phosphorus in sediments, which has no notable source within the ocean, and the radiogenic strontium isotopes in Archean carbonates indicate that, prior to the Great Oxidation Event (GOE), subaerial expanses represented only about $20 \%$ of the modern continental surface area, i.e. $7 \%$ of the surface of the Earth. Because these simple first-order observations, in contrast to the low 40 oxygen content of the pre-GOE atmosphere, have so far received only little attention in the appraisal of the marine chemistry of the early Earth, a reassessment of the chemistry of the pre-GOE ocean is warranted. Here we discuss some of the geochemical cycles of the Archean world, including protons, alkalinity, electrons, and other electrolytes, and attempt to build a first conceptual framework for Chemical Archeoceanography. The smaller subaerial exposures characterizing the Archean and the low abundance of Archean carbonates and mudstones imply that the flux of alkalinity to the ocean was much weaker than today and therefore that the capacity of the runoff to neutralize the high-temperature hydrothermal fluids was less important. Such a reduced flux in turn entails lower seawater $p H$ and higher chlorinity. The lack of atmospheric $\mathrm{O}_{2}$ allowed iron to be in its soluble $\mathrm{Fe}(\mathrm{II})$ form and to reduce $\mathrm{HCO}_{3}^{-}$to $\mathrm{CH}_{4}$ while liberating large amounts of protons. The low $\mathrm{pH}$ of the pre-GOE 
ocean and the reduced alkalinity input, reinforced by scant $P$ supply, account for reduced carbonate precipitation. Ocean chemistry evolved under the control of two changing factors: (i) the balance between chemical weathering and hydrothermal fluxes and (ii) the oxygen pressure in the ocean and the atmosphere. Seawater iron concentration was controlled by 55 high $\left[\mathrm{Fe}^{2+}\right] /\left[\mathrm{H}^{+}\right]^{2}$ ratios. The temperature of hydrothermal fluids at mid-ocean ridges and in other active volcanic edifices being determined by the expansion properties of seawater, the chemistry of hydrothermal fluids is controlled by the chlorinity of the ocean. Of all the major element cycles in seawater, those of $\mathrm{Na}, \mathrm{Mg}$ and $\mathrm{P}$ seem to be unbalanced when runoff falls below the modern value. The very low $P$ content of banded iron formations is inconsistent 60 with a major role of biological activity in the oxidation of $\mathrm{Fe}^{2+}$ dissolved in the Archean ocean. Prior to the GOE, banded iron formations were the major sedimentary sink of seawater cations, a role now played by carbonates. The controls of seawater alkalinity, which today are exerted by the $\mathrm{Ca}^{2+}-\mathrm{CaCO}_{3}$ couple, was exerted by dissolved $\mathrm{Fe}^{2+}$-magnetite or or $\mathrm{Fe}^{2+}$-ferrihydrite.

65 Keywords: Archean ocean chemistry; methane; geochemical cycles; continental surface; runoff; hydrothermal fluids

\section{Introduction}

The ocean prior to the Great Oxidation Event (GOE) some 2.4 Gy ago differed from its modern counterpart in many compositional, physiographic, and dynamic aspects. The most dramatic difference in the physics of the Archean ocean was the smaller extent of subaerial continental expanses (Arndt, 1999; Kump and Barley, 2007). Although it is firmly established that continents have grown over time (Hurley and Rand, 1969; Reymer and Schubert, 1984), it is still not clear how much of the crust stood above sea level at any given time, in particular 
because the assumption of constant freeboard can be evaluated only for post-Precambrian 75 times (Wise, 1973).

An Archean world with reduced continental surface would have been very different from the familiar Cenozoic 'conveyor belt' (Broecker and Peng, 1982), in which oceanic circulation is shaped by a particular plate configuration and deep-water formation reflects the distribution and latitude of continents. In the modern ocean, most of the runoff ends up in the Atlantic 80 Ocean with its load of nutrients and alkalinity, whereas the receiving end of mechanical transport is in the Indian and the Pacific Oceans. By contrast, a world with little land mass would be more akin to aquaplanets, such as in the models of Smith et al. (2006) and Marshall et al. (2007). Ocean circulation would be dominated by zonal jets with a transport pattern resembling that of the Circum-Antarctic Current. A water world has no equivalent of the Gulf 85 Stream and deep-water masses are difficult to form by processes similar to those operating in the modern Norwegian and Weddell seas. Gyres would not exist and ocean circulation would be reduced to broad eastward jets at mid-latitude separated by an intertropical westward jet. Winds and deep tides, not buoyancy, would force oceanic circulation and vertical mixing (Ferrari and Wunsch, 2009; Wunsch and Ferrari, 2004). Maintaining a stratified ocean 90 (Beukes et al., 1990; Klein and Beukes, 1989; Lowe, 1980) therefore would require special circumstances. Understanding the chemistry of a mostly submerged Archean and pre-GOE world is an important challenge.

The issue of the extent of exposed surface is particularly important because weathering, both today and during the Precambrian, is by far the most important sink of atmospheric $\mathrm{CO}_{2}$, 95 thereby rendering continents the main source of alkalinity which is eventually stored in carbonates. It took the re-examination of Sr isotopes in marine carbonates through time (Flament et al., 2008) to promote the idea that the divergence of marine ${ }^{87} \mathrm{Sr} /{ }^{86} \mathrm{Sr}$ from the mantle evo- 
lution curve at 2.7-2.4 Ga is not so much a marker of crustal growth as of onset of massive

continental weathering. Calcium carbonates were much less abundant in the Archean than today (Cameron and Baumann, 1972; Engel et al., 1974; Grotzinger, 1989; Lowe, 1980; Ronov, 1968), and whatever carbonate did form as stromatolites and other microbialites was restricted to continental shelves (Buick et al., 1998; Grotzinger, 1989; Lowe, 1980) and lakes (Flannery et al., 2016). Precipitation of carbonates in lakes and on continental shelves is controlled by the input of alkalinity and phosphorus. It is unlikely that ancient carbonates have been lost as compelling reasons for why they would have been selectively removed from the sedimentary record are missing.

The chemistry of ancient oceans is a topic that has been addressed repeatedly in the literature (Coogan et al., 2019; Grotzinger and Kasting, 1993; Holland, 1984; Lyons et al., 2014; Morse and Mackenzie, 1998; Walker et al., 1983) with rather diverging conclusions. Seawater composition is controlled by elemental sources and sinks, while the pace of elemental throughput is via adsorption on particles and biological activity. The main sources are continental runoff and hydrothermal vents, while the main sinks are sediments. Other sources and sinks are submarine volcanic exhalations and hydrothermal alteration of the oceanic crust by percolating seawater, the latter of which acts as both a source and a sink while the former is 115 solely a source.

In principle, because runoff intensity and water-rock interaction at the bottom of the ocean may have varied through time, the $\delta^{18} \mathrm{O}$ record of marine carbonates and silica should help us interpret changes in the water cycle associated with evolving chemical fluxes. This record shows both scatter and trends and has been receiving conflicting interpretations in the literature. To some authors, the signal is significant and is used to trace the history of land emergence and hydrothermal water fluxes (Bindeman et al., 2018; Jaffrés et al., 2007; Johnson 
and Wing, 2020). To others, carbonate diagenesis is ubiquitous, both at the bottom of the sea and on land, with severe effects on both conventional and clumped isotopes (Derry, 2010; Edgar et al., 2015; Leutert et al., 2019). Unless the minimum assumption of no correlation 125 between $\delta^{13} \mathrm{C}$ and $\delta^{18} \mathrm{O}$ is verified, ancient carbonates should always be considered diagenetically altered at best and metamorphic in most cases. In addition, most Archean carbonates are platform sediments (Grotzinger, 1989; Kamber and Webb, 2001; Klein and Beukes, 1989) and enrichment of surface water in ${ }^{18} \mathrm{O}$ due to evaporation (Craig et al., 1963; Kim and Lee, 2011) is another serious limitation to robust interpretations.

130 The present work addresses the dynamic regime of the pre-GOE ocean and its associated geochemical cycles. Emphasis will be placed on the effect that continent rise above sea level has on oceanic circulation, seawater and atmosphere chemistry, nutrient availability, and sediment composition. The role of methane and carbon dioxide in defining the composition of the ocean and the atmosphere further will be re-evaluated, leading to a revised representation 135 of the Archean ocean-atmosphere system and a new understanding of the GOE. 


\section{The controls on ocean chemistry}

For the sake of illustrating the discussion, a simplified model of the pre-GOE ocean electrolyte chemistry is depicted in Figure 1.

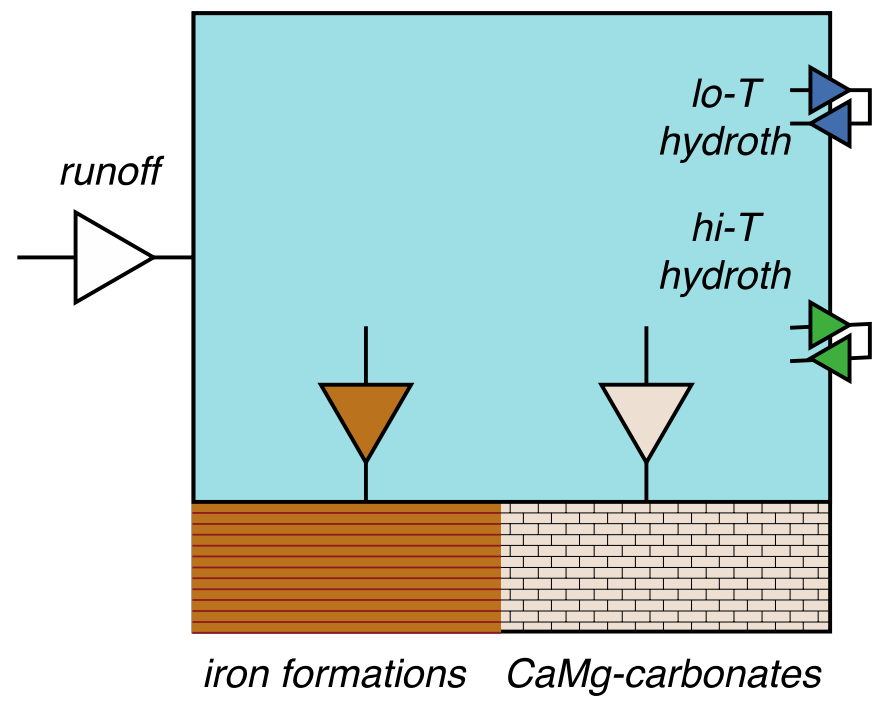

140 Figure 1. A simple box-model representation of the pre-GOE ocean. Runoff is a first-order input (left), chemical sediments (carbonates and oxyhydroxides) a first-order output (right). Interaction between seawater and the oceanic crust at high (mid-ocean ridge crests) and low (midocean ridge flanks and marine volcanoes) temperature combines outputs of seawater and inputs of hydrothermal fluids. This model can be evaluated for the modern ocean using the numbers in 145 Table 1.

Seawater chemistry is controlled by (i) the runoff and, therefore, the atmospheric $P_{\mathrm{CO}_{2}}$ and the extent of subaerial continental expanses; (ii) hydrothermal activity associated with midocean ridges, which today produce about $3.0-3.5 \mathrm{~km}^{2} \mathrm{a}^{-1}$ of new oceanic crust (Becker et al., 2009; Sclater et al., 1981) and account for 95\% of volcanic activity; (iii) off-axis, low150 temperature alteration; and (iv) chemical sedimentation (carbonates, and before the GOE, banded iron formations, or BIF). Item (i) is an input to the ocean, (iv) an output, while (ii) 
and (iii) combine the output of unfractionated seawater into the oceanic crust with the input of hydrothermal solutions. The mass balance equation for element $i$ in seawater reads

$$
M_{S W} \frac{d C_{s w}^{i}}{d t}=\Phi_{r i v} C_{r i v}^{i}-\Phi_{c h} C_{c h}^{i}+\Phi_{H T}\left(C_{H T}^{i}-C_{s w}^{i}\right)+\Phi_{L T}\left(C_{L T}^{i}-C_{s w}^{i}\right)
$$

155 where $C^{i}$ stands for the concentration of element $i$ in seawater (sw), rivers (riv), chemical sediments (ch), high-temperature vents $(H T)$, and low-temperature fluids $(L T) . \Phi$ stands for mass fluxes. Time is noted $t$ and $M_{s w}$ is the mass of the ocean. The residence time $\tau_{i}$ of element $i$ is given by

$\tau_{i}=\frac{M_{S W}}{\Phi_{H}+\Phi_{c h} D_{c h}^{i}}$

160 where $\Phi_{H}=\Phi_{H T}+\Phi_{L T}$ and $D_{c h}^{i}$ is the fractionation coefficient of element $i$ between chemical sediments and seawater. At steady state:

$C_{S W}^{i}=C_{H T}^{i}+f_{L T}\left(C_{L T}^{i}-C_{H T}^{i}\right)+\frac{\Phi_{r i v}}{\Phi_{H}} C_{r i v}^{i}-\frac{\Phi_{c h}}{\Phi_{H}} C_{c h}^{i}$

in which $f_{L T}$ is the fraction of hydrothermal solutions emitted at low temperature. From a long-term geological perspective, we will focus on the main parameters controlling the 165 steady-state concentrations. We recognize in this equation the riverine and hydrothermal inputs on the one hand and the outputs on the other hand (seawater feeding the hydrothermal systems and chemical sediments).

This simple model can to some extent be tested on modern seawater. Estimates exist for the fluxes of some major elements (Table 1). However, given the modern climatic fluctuations, it 170 is difficult to assess whether these values are representative of long-term fluxes for time scales in excess of the major element residence times, $(\sim 10 \mathrm{Ma})$. We therefore allowed for uncertainty by introducing correction factors to some of the fluxes. 


\begin{tabular}{|c|c|c|c|c|c|c|}
\hline \multirow[b]{3}{*}{ factor } & $f_{L T}$ & \multirow{2}{*}{$\begin{array}{l}\Phi_{H} \\
1.0010^{14}\end{array}$} & \multirow{2}{*}{$\begin{array}{l}\Phi_{\text {riv }} \\
3.7310^{16}\end{array}$} & \multirow{2}{*}{$\begin{array}{l}\Phi_{c h} \\
4.010^{12}\end{array}$} & & \\
\hline & 0.4 & & & & & \\
\hline & 1 & 1 & 1.094 & 0.3945 & & \\
\hline gat $/ \mathrm{kg}$ & $C_{H T}^{i}$ & $C_{L T}^{i}$ & $C_{\text {riv }}^{i}$ & $C_{c h}^{i}$ & $C_{S W}^{i}$ calc & $C_{S W}^{i}$ meas \\
\hline Alk & 0 & 0 & 0.001 & 25.7 & 0.0023 & 0.0024 \\
\hline $\mathrm{Ca}^{2+}$ & 0.0156 & 0.0102 & 0.00038 & 10 & 0.01 & 0.01 \\
\hline $\mathrm{Mg}^{2+}$ & 0 & 0 & 0.00014 & 2.9 & 0.01 & 0.01 \\
\hline $\mathrm{Na}^{+}$ & 0.432 & 0.336 & 0.00026 & 0 & 0.5 & 0.48 \\
\hline $\mathrm{Sr}^{2+}$ & $8.1010^{-5}$ & $9.7010^{-5}$ & $8.9010^{-7}$ & $2.2910^{-2}$ & $9.010^{-5}$ & $8.6010^{-5}$ \\
\hline $\mathrm{K}^{+}$ & 0.0232 & 0.00625 & $3.2510^{-5}$ & 0 & 0.0297 & 0.0104 \\
\hline $\mathrm{Rb}^{+}$ & $2.8010^{-5}$ & $1.0710^{-6}$ & 0 & 0 & $1.7210^{-5}$ & $1.3010^{-6}$ \\
\hline $\mathrm{Li}^{+}$ & $8.9110^{-4}$ & $7.3010^{-5}$ & 0 & 0 & $5.6410^{-4}$ & $2.6010^{-5}$ \\
\hline
\end{tabular}

175 Table 1. Upper panel: fraction $f_{L T}$ of the low-temperature hydrothermal fraction of off-axis hydrothermal fluids and mass fluxes $\Phi$. The value $f_{L T}=0.4$ is consistent with Hasenclever et al. 's (2014) estimate. The modern runoff value of $3.7310^{16} \mathrm{~kg} \mathrm{a}^{-1}$ was taken from (Wu et al., 2016). The flux of Ca carbonates of $4.010^{12} \mathrm{~kg} \mathrm{a}^{-1}$ was taken from (Mackenzie and Morse, 1992) and the adopted calcite/dolomite molar ratio of 3.5 is consistent with Milliman's 180 (1993) estimates. A $\Phi_{H}$ value of $1.010^{14} \mathrm{~kg}$ a-1 (total hydrothermal water flux) is consistent with Hasenclever et al.'s (2014) estimate for 40,000 km of fast-spreading ridges similar to the East Pacific Rise and with Palmer and Edmond's (1989) estimate from Sr isotopes. Lower panel, inputs (first three columns): concentrations of high-and low-temperature hydrothermal solutions. The $21^{\circ} \mathrm{N}$ site on the East Pacific Rise (Von Damm, 1990b) is representative of the high-temperature component because its $\mathrm{Cl}$ content indicates little liquid-vapor separation. Likewise, fluids from hole 504B, ODP leg 137 extrapolated at Mg=0 (Magenheim et al., 1995) can be chosen as the low-temperature end-member. Lower panel, outputs: runoff values from Berner and Berner (2012) and sedimentary carbonate composi- 
tion (ch) from Mackenzie and Morse (1992). The last two columns compare the calculated and measured seawater compositions.

The conservative, non-redox $\mathrm{Na}, \mathrm{Ca}, \mathrm{Mg}$, and $\mathrm{Sr}$ concentrations calculated for seawater are consistent with the observed values to within a few percent on the condition that the car195 bonate flux is reduced by a factor of $\sim 3$ (see Table 1). This solution is not unique and a range of alternative solutions can be obtained by changing the values of $\Phi_{\text {riv }}$ and $\Phi_{c h}$. Modelled seawater $\mathrm{K}, \mathrm{Rb}$, and $\mathrm{Li}$ concentrations are significantly too high, which signals that these elements are lost via their adsorption on clay minerals, a process not captured by the model. The overall agreement between predictions and observations, however, suggests that this 200 simple model also provides an acceptable framework for the Archean ocean and shows that the modern seawater composition can be accounted for by a simple combination of realistic inputs and outputs. Of course, the solution is still underdetermined because fluxes, and the interval over which they apply, are not constrained with a high degree of certainty.

\subsection{The rise of continents and the changing runoff}

205 Arndt (1999) first pointed out that many Archean and Proterozoic greenstone belts contain volcanic rocks that erupted subaqueously. Subaerial stretches of land are known from Pilbara, Australia (Buick et al., 1995), 3.4 Gy ago and from Kaapvaal, South Africa (Eriksson et al., 2006), 3.25 Gy ago, while eolianites (Simpson et al., 2012) make a strong case for a continental environment. Very low sedimentation rates observed for mudstones around Archean 210 greenstone belts (Kamber and Tomlinson, 2019; Thurston et al., 2008) confirm that only a small fraction of volcanic edifices was standing above sea level and prone to weathering. Additional evidence in favor of reduced continental expanses in the Archean was discussed 
by Flament et al. (2008), who argued that the ${ }^{87} \mathrm{Sr} /{ }^{86} \mathrm{Sr}$ ratio of the carbonate record tracks the surface area of emerged land submitted to chemical erosion. The ${ }^{87} \mathrm{Sr} /{ }^{86} \mathrm{Sr}$ of seawater and of carbonates precipitated from the ocean reflects the balance between hydrothermal and riverine inputs. ${ }^{87} \mathrm{Sr} /{ }^{86} \mathrm{Sr}$ of the high-temperature hydrothermal fluids is $\sim 0.703-0.704$ (Albarède et al., 1981), unambiguously reflecting interaction of the fluids with the low- $\mathrm{Rb} / \mathrm{Sr}$ upper mantle. The modern riverine input has ${ }^{87} \mathrm{Sr} /{ }^{86} \mathrm{Sr}$ of $\sim 0.711$ (Palmer and Edmond, 1989), which equally unambiguously reflects the high $\mathrm{Rb} / \mathrm{Sr}$ ratio and the old mean age of the crust. Veizer and Compston (1976) observed that the ${ }^{87} \mathrm{Sr} /{ }^{86} \mathrm{Sr}$ record of marine carbonates began diverging from mantle values in the early Proterozoic, while Kamber and Webb (2001) argued that the divergence took place at about 2.5 Ga. Flament et al. (2008) used geophysical modeling to predict that the pre-GOE world had less than $10 \%$ of its surface exposed to subaerial erosion.

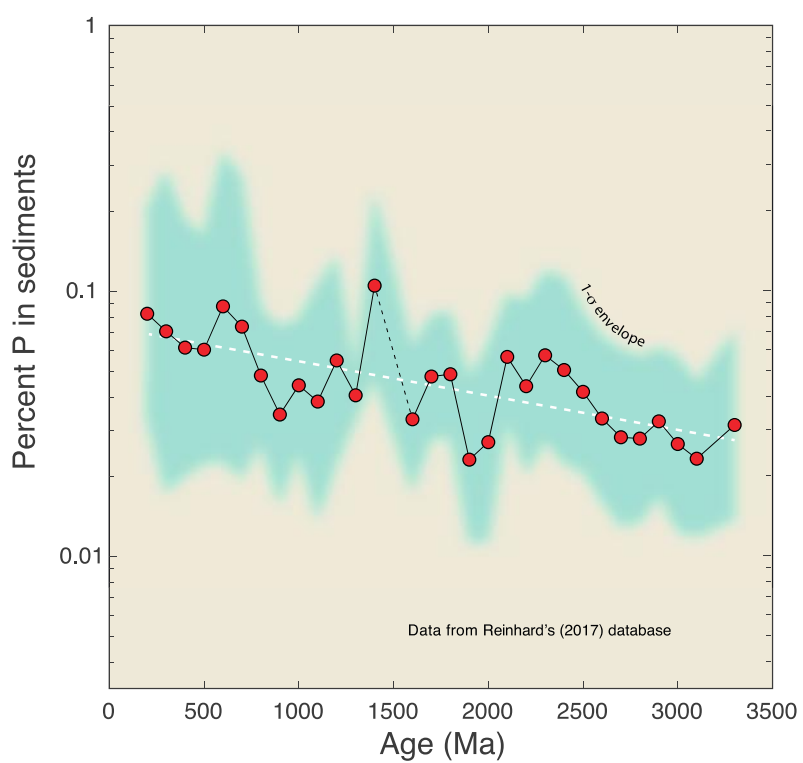

Figure 2. The evolution of phosphorus concentrations in $~ 8000$ samples of marine sediments from the geological record (Reinhard et al., 2017). The red circles represent the average of the data binned by 100 My slices. The blue shaded area is the $1 \sigma$ confidence interval. The white dotted line is an exponential fit to the average values. Phosphorus rises continuously 
by, on average, 34\% per Gy. The GOE ( 2.4 Ga) does not seem to be associated with a sharp

increase of phosphorus and therefore does not mark a sudden rise of continents above sea level.

The sedimentary phosphorus record also attests to reduced land surface in the Archean. Phosphorus is an essential bio-limiting element present in adenosine-triphosphate, phospho235 lipids, and nucleic acids. The exogenous $\mathrm{P}$ cycle will be addressed in a subsequent section but it is well established that the only significant phosphorus input to the ocean is runoff, whereas both mid-ocean ridges, ridge flanks, and sediments, except when organic-rich, act as sinks (Baturin, 2003; Ruttenberg, 1993; Wheat et al., 2003). Campbell and Allen (2008) suggested that periods of supercontinent formation coincided with enhanced flux of this element to the 240 ocean. What is measured in sediments today entered the ocean in three forms: dissolved, clastic, and reactive (absorbed on FeMn-hydroxides). Prior to the GOE, the latter can be minimized because $\mathrm{Fe}(\mathrm{II})$ was soluble. Soluble P residence time (=oceanic load/output) in the modern ocean is short (20 to $100 \mathrm{kyr}$ (Paytan and McLaughlin, 2007)). Biological recycling and diagenesis would affect $\mathrm{P}$ residence time in the pre-GOE ocean, but not the long-term $\mathrm{P}$ 245 sedimentary output.

Phosphorus concentration in mudstones expresses the ratio between chemical and mechanical erosion. As such, the $\mathrm{P}$ abundance in mudstones can be used to infer continental surface area. The reliability of $\mathrm{P}$ contents of mudstones rests on two conservative assertions: (1) what goes around comes around, and hence, after a few residence times, sediments must reflect whatev250 er is removed from continents, regardless of the ocean composition; and (2) subduction zones remove sediments in bulk, not selectively. Phosphorus abundance in mudstones is to some extent affected by local productivity. It should also vary with the ratio between coarse detrital sediments and mudstones, which probably accounts for some of the dispersion in Reinhard et 
al.'s (2017) compilation. The sheer number of samples in this database ensures, however, that 255 the mean values cannot be too far off. Phosphorites (apatite), which did not become a significant contributor to the P sedimentary budget before the Neo-Proterozoic (Cook et al., 2005), are not a major source of uncertainty. Likewise, aluminum phosphate interspersed in diagenetic or metamorphic quartzites is not known before the GOE (Morteani et al., 2007). Remarkably, the super-events of continental assembly (Campbell and Allen, 2008) do not 260 show up as peaks in Reinhard et al.'s (2017) compilation (Figure 2), suggesting that the ratio of chemical to mechanical erosion during these events is not strongly influenced by plate tectonics.

Even though some authors have previously emphasized the contrast in P contents between Archean and modern sediments (Bjerrum and Canfield, 2002; Reinhard et al., 2017), reevaluation of Reinhard et al.'s (2017) mudstone database including a log-normal distribution and its statistical dispersion (Figure 2) shows a steady, continuous rise through time of the $\mathrm{P}$ sedimentary output right through and unaffected by the GOE, an observation that is most simply interpreted to reflect a continuous increase of riverine fluxes with age $T(\mathrm{Ga})$ following the relation

$\mathrm{P}(w t \%)=0.0024 \times 10^{-0.3( \pm 0.1) T}$

Since input must balance output there is no 'hidden source' of $\mathrm{P}$ in the ocean and, hence, low$\mathrm{P}$ sediments in the past dictates that the surface area of emerged continents in the Archean and Paleoproterozoic be smaller than today. Given that continents represent $30 \%$ of Earth's surface today, it can be inferred that they were covering only $\sim 7 \%$ of Earth's surface at the 275 time of the GOE, which is consistent with the quantitative prediction by Flament et al. (2008). 


\subsection{Chemical sedimentation}

A first output channel is the sedimentation of CaMg-carbonates, which regulates the alkalinity of the modern ocean. The striking scarcity of marine carbonates in the Archean geological 280 record with respect to its Proterozoic and Phanerozoic counterparts, first identified decades ago (Pettijohn, 1943), was reviewed 40 years ago (e.g., (Lowe, 1980) and references therein). Until rather recently, the consensus held that carbonates, notably calcium carbonates, were inconspicuous in the Archean rock record and, consequently, were considered a trace component found largely at major breaks within volcanic sequences (Lowe, 1980). Even the most 285 spectacular carbonate sections in the Archean sedimentary record remain relatively thin, e.g. the Wittenoom dolomites (Jahn and Simonson, 1995), the Dresser ankerite and the Strelley Pool Chert dolomite from Pilbara, Australia (Van Kranendonk et al., 2003), and calcite from the Campbellrand-Malmani sequence of the 2.5 Ga old Kaapvaal Craton, South Africa (Kamber and Webb, 2001; Sumner, 1997). The assumption that carbonates were less well 290 preserved than other rock types as a result of their deposition as supracrustal rocks is immaterial to this conclusion, simply because whatever carbonate was dissolved must have been quickly re-precipitated at sea. Alkalinity is conservative and Archean Ca fluxes to the ocean, therefore, must have been smaller than at later times.

A second output channel is represented by $\mathrm{Fe}$ - and Mn-oxides and oxihydroxides, which 295 form a complex family of minerals (Lemire et al., 2013; Majzlan et al., 2004). Two distinct types of reactions affect Fe compounds: hydrolysis and redox transformations. In the modern ocean, typical chemical sediments are FeMn-nodules and encrustations, in which Fe is in the $\mathrm{Fe}(\mathrm{III})$ form. In the pre-GOE world, magnetite $\left(\mathrm{Fe}_{3} \mathrm{O}_{4}\right)$, which dominates BIF sediments, is often considered diagenetic, and ferrihydrite $\left(\mathrm{FeO}(\mathrm{OH})\right.$ or $\left.\mathrm{Fe}_{2} \mathrm{O}_{3}-x \mathrm{H}_{2} \mathrm{O}\right)$ is a probable precur300 sor (Konhauser et al., 2017). Regardless of magnetite's status with respect to diagenesis, au- 
thors have stressed both the prevalence of this mineral in Archaean BIF and the delicacy of the microstructures it preserves (Li et al., 2017).

\subsection{The mid-ocean ridge hydrothermal systems}

The temperature range of hydrothermal venting along mid-ocean ridges and back-arcs, at 305 typically $360-420^{\circ} \mathrm{C}$, is a result of water thermal expansion and compressibility rising sharply near the critical point (Bischoff and Rosenbauer, 1985; Coogan et al., 2019) and, hence, the effect of water depth should be secondary. The same argument applies to most submarine volcanic activity, such as greenstone belts. Above this temperature range, hydrothermal fluids separate into a low-chlorinity solution and a brine (Von Damm et al., 2003). At a given tem310 perature, the element concentrations and the $\mathrm{pH}$ of hydrothermal solutions at mid-ocean ridges are tightly controlled by a series of buffer reactions, typically those of the greenschist facies, informally reading as $\left[\mathrm{M}^{\mathrm{n}+}\right] /\left[\mathrm{H}^{+}\right]^{\mathrm{n}}=$ Const. (where $\mathrm{M}$ stands for any metal). For basaltic lithologies, the dominant minerals are albite, epidote, chlorite, and actinolite \pm paragonite (Bowers and Taylor, 1985). Examples of such reactions are (with the buffered element in 315 parenthesis):

2 tremolite +3 chlorite $+50 \mathrm{H}^{+} \leftrightharpoons 2$ clinozoisite $+19 \mathrm{SiO}_{2}+38 \mathrm{H}_{2} \mathrm{O}+25 \mathrm{Mg}^{2+}(\mathrm{Mg})$

$2 \mathrm{Fe}$-actinolite $+3 \mathrm{Fe}$-chlorite $+50 \mathrm{H}^{+} \leftrightharpoons 2$ clinozoisite $+19 \mathrm{SiO}_{2}+38 \mathrm{H}_{2} \mathrm{O}+25 \mathrm{Fe}^{2+}(\mathrm{Fe})$

$3 \mathrm{Mg}$-actinolite +2 epidote $+20 \mathrm{H}^{+} \leftrightharpoons 3$ chlorite $+21 \mathrm{SiO}_{2}+2 \mathrm{H}_{2} \mathrm{O}+10 \mathrm{Ca}^{2+}(\mathrm{Ca})$

5 albite + tremolite $+\mathrm{H}_{2} \mathrm{O}+5 \mathrm{H}^{+} \leftrightharpoons$ clinozoisite $+\mathrm{Mg}$-chlorite $+17 \mathrm{SiO}_{2}+5 \mathrm{Na}^{+}(\mathrm{Na})$

\section{2.4. Low-temperature marine sources and sinks}

This issue has been addressed repeatedly for the modern oceanic crust but only with moderate success. Low-temperature processes (subaerial weathering and alteration of the oceanic crust at temperatures $\leq 100^{\circ} \mathrm{C}$ ) cannot be handled within the same simplified framework for a number of reasons. In this environment, the primary control of boiling temperature is water 
depth (Bischoff and Rosenbauer, 1985). Many phases, notably paragonite (Stroncik and

Schmincke, 2002) are composite of different alteration products. Typically, clay minerals and zeolites formed by off-axis, low-temperature alteration of the oceanic crust should react with each other, but the clay minerals are rarely pure enough to act as buffers and form mixedlayer phases and complex solid solutions. Equilibrium is also hindered by the low tempera330 ture, and thermodynamic properties are difficult to validate (e.g., (Blanc et al., 2015; Ransom and Helgeson, 1994). Evidence of alkali element uptake by the upper basaltic section is not consistent with the expected proton uptake at low temperature. Data on drill holes such as at the ODP 504B site shows, instead, that their abundance in the upper crust results from the overprint of alteration phases over a wide range of temperatures (Alt et al., 1996) giving rise

335 to an ambiguous metamorphic rock record. For $\mathrm{Mg}$ and $\mathrm{Ca}$, even the direction of change is problematic (Paul et al., 2006)\}. One observation stands out: alteration of the oceanic crust at low temperatures is a significant sink for seawater carbonates (Alt and Teagle, 1999). Since low-temperature alteration of the oceanic crust leads to Na replacing $\mathrm{Ca}$, and $\mathrm{Si}$ replacing $\mathrm{Al}$, silicification, albitization, and carbonatization proceed hand-in-hand. For many elements,

340 borehole fluid data (e.g., (Magenheim et al., 1995; Wheat et al., 2003) are probably more relevant to water-rock exchange at low temperatures than data on the rocks themselves. Overall, in contrast to the rather clean evidence from high-temperature hydrothermal vents at mid-ocean ridges, how much low-temperature alteration contributes to the ocean budget is still unclear.

\section{3. Equilibria in Archean seawater}

This section considers the balance of protons, electrons, and alkalinity together with the cycles of selected elements critical to Archean seawater. The two most important factors are:

(1) because of the lack of oxygen in the pre-GOE atmosphere, $\mathrm{SO}_{4}^{2-}$ and $\mathrm{NO}_{3}^{-}$, which dominate the redox chemistry of modern seawater, were essentially absent, and iron was overwhelm- 
ingly in its $\mathrm{Fe}^{2+}$ form; and (2) despite recent attempts (Marty et al., 2018), the [ $\left.\mathrm{Cl}^{-}\right]$content of

\subsection{The charge balance}

The alkalinity concept is central to our understanding of the evolution of the ocean/atmosphere system because, contrary to any other parameter of the carbonate system

$355\left(\mathrm{pH}, \mathrm{P}_{\mathrm{CO} 2},\left[\mathrm{HCO}_{3}^{-}\right],\left[\mathrm{CO}_{3}^{2-}\right]\right)$ and dissolved inorganic carbon or DIC aka $\left.\sum \mathrm{CO}_{2}\right)$, it is conservative upon exchange with the atmosphere. In addition, the record of chemical sediments (i.e. carbonates and oxides), provides a record of the oceanic sinks of alkalinity. As today, juvenile alkalinity (about 50\% of the total (Gaillardet et al., 1999)) is produced upon weathering of silicates by $\mathrm{CO}_{2}$-rich meteoric water (Garrels and Mackenzie, 1971), while recycled 360 alkalinity corresponds to the weathering of sedimentary carbonates. Both are eventually unloaded from the ocean as carbonate sediments.

A core factor of geochemical cycles is that in essentially all the natural fluids but rain, the abundance of $\left[\mathrm{H}^{+}\right]$is small with respect to those of major cations. Consequently, relatively minor transfers of electrolytes from the rock to the fluid, notably the most abundant $\mathrm{Na}$ and $365 \mathrm{Cl}$, causes very large changes in $\mathrm{pH}$.

In modern seawater, the charge deficit of anions $\left(\mathrm{Cl}^{-}, \mathrm{SO}_{4}^{2-}\right)$ relative to cations $\left(\mathrm{Na}^{+}, \mathrm{K}^{+}\right.$, $\left.\mathrm{Mg}^{2+}, \mathrm{Ca}^{2+}\right)$ is mostly compensated by $\mathrm{HCO}_{3}^{-}$and $\mathrm{CO}_{3}^{2-}$. Ignoring borates, the present-day carbonate alkalinity

$A l k \approx\left[\mathrm{HCO}_{3}^{-}\right]+2\left[\mathrm{CO}_{3}^{2-}\right] \approx\left[\mathrm{Na}^{+}\right]+2\left[\mathrm{Mg}^{2+}\right]+2\left[\mathrm{Ca}^{2+}\right]-\left[\mathrm{Cl}^{-}\right]-2\left[\mathrm{SO}_{4}^{2-}\right]$

370 is a small quantity of the order of $2 \times 10^{-3}$ meq $\mathrm{L}^{-1}$, to be compared with 546 meq $\mathrm{L}^{-1}$ of $\mathrm{Cl}^{-}$(Figure 3). 


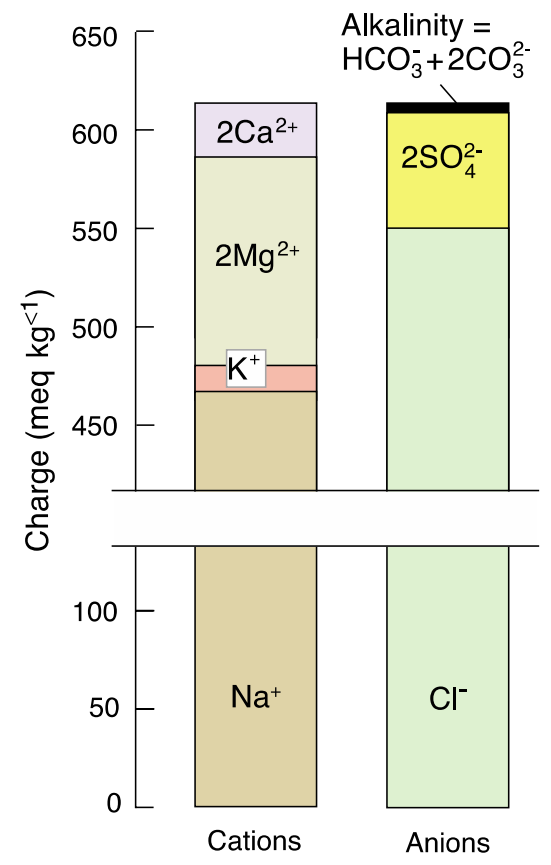

MODERN

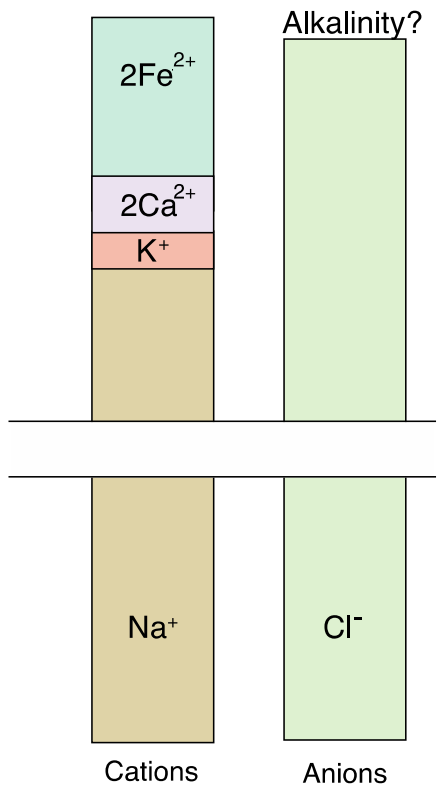

ARCHEAN

Figure 3. Charge balance (alkalinity) in modern seawater compared to what it might have been in the Archean world with only a small proportion of emerged continents. Concentra375 tions for Archean seawater are only tentative and are shown for the sake of illustration: lower chlorinity, high Fe contents, lack of Mg because of a much reduced runoff. With muchreduced runoff, $\mathrm{Mg}^{2+}$ and $\mathrm{Ca}^{2+}$ are far less concentrated, while $\mathrm{SO}_{4}^{2-}$ is reduced and removed as iron sulfide. Phosphate (too dilute to be shown) is extremely low.

In pre-GOE times, the charge balance of the ocean must have been quite different. The sea380 water concentrations of $\mathrm{Mg}^{2+}$, which is removed quantitatively at ridge crests (Edmond et al., 1979b), would have been reduced in proportion to the area of emerged continental expanses, while under low $P_{\mathrm{O} 2}$ conditions, $\mathrm{SO}_{4}^{2-}$ and $\mathrm{NO}_{3}^{-}$were negligible. Accordingly, an approximate charge-balance condition of the Archean ocean is

$\left[\mathrm{Na}^{+}\right]+\left[\mathrm{K}^{+}\right]+2\left[\mathrm{Ca}^{2+}\right]+2\left[\mathrm{Fe}^{2+}\right] \approx\left[\mathrm{Cl}^{-}\right]+$Alk 
By virtue of the simple relationship $1 / 2 A l k<$ DIC $<A l k$, alkalinity strictly brackets the amount

of $\mathrm{CO}_{2}$ that can be dissolved in the ocean. Since maximum fluid eruption temperature is essentially determined at mid-ocean ridges by water thermal expansion and compressibility (Bischoff and Rosenbauer, 1985), alkalinity and, more generally, the composition of hydrothermal fluids are largely controlled by their chlorinity.

390 The carbonate content of Archean meteoric water and, therefore, weathering intensity are unknown. However, a high- $\mathrm{CH}_{4} / \mathrm{CO}_{2}$ atmosphere (Haqq-Misra et al., 2008; Thibon et al., 2019; Zahnle et al., 2019) does not support strong alkalinity transport in the runoff. Moreover, at the time of the GOE, little alkalinity had been stored as sedimentary carbonates. From this follows that alkalinity in the runoff was restricted to the fraction corresponding to silicate 395 weathering (juvenile alkalinity). Finally, the extent of emerged land was small, which should have further reduced the flow of alkalinity to the ocean. It is thus surmised that seawater alkalinity was quite low, much lower than today.

\subsection{The proton balance and the chlorine question}

A weaker drainage of ancient continents must have been equivalent to a reduced neutralizing 400 capacity of the fluids emitted by high-temperature vents at mid-ocean ridges. In a landmark paper written in the wake of the discovery of the Galapagos hydrothermal vents, Edmond et al. (1979a) reformulated the then classic description of weathering processes. 'Reverse weathering' (Sillén, 1961) assumes that cations produced upon continental weathering are reprecipitated in the ocean as authigenic clay, a process that replenishes seawater with the 405 protons lost on continental surfaces. Edmond et al. (1979a) demonstrated, however, that although runoff is depleted in protons by weathering, seawater is 'back-titrated' at high temperatures at mid-ocean ridges, where protons are produced in abundance, rather than by the for- 
mation of authigenic clay (Isson and Planavsky, 2018) which, even on the seafloor, cannot be regarded as a significant proton source (Wheat et al., 2004).

Alteration of albite to paragonite mica in the greenschist facies is a good example:

3 albite $+2 \mathrm{H}^{+}$与 paragonite +6 silica $+2 \mathrm{Na}^{+}$

A critical element of explanation is that any rock-water reaction at temperature $T$ similar to this reaction is ruled by the van t'Hoff's equation

$\frac{d \ln K}{d T}=\frac{\Delta H_{r}}{R T^{2}}$

415 This equation, which relates the equilibrium constant $K$ of the reaction, its enthalpy change $\Delta H_{r}$, and the gas constant $R$, indicates that, at silica saturation, the ratio $\left[\mathrm{Na}^{+}\right] /\left[\mathrm{H}^{+}\right]$of the above equation quickly decreases with temperature. Figure 4 plots $\left[\mathrm{M}^{n+}\right] /\left[\mathrm{H}^{+}\right]^{n}$ derived from Arnorsson et al.'s (1983) equations in order to account for Icelandic geothermal fluids between 50 and $300^{\circ} \mathrm{C}$. For instance, the $300^{\circ} \mathrm{C}$ value is consistent with the $\left[\mathrm{Na}^{+}\right]$concentration (300-500 $\mathrm{mM} \mathrm{kg}^{-1}$ ) and the $\mathrm{pH}$ reported for several hydrothermal vent fields of the global mid-ocean ridge system (German and Von Damm, 2006; Von Damm, 1990a). As indicated above, changes in equilibrium constants are dominated by changes in $\left[\mathrm{H}^{+}\right]$.

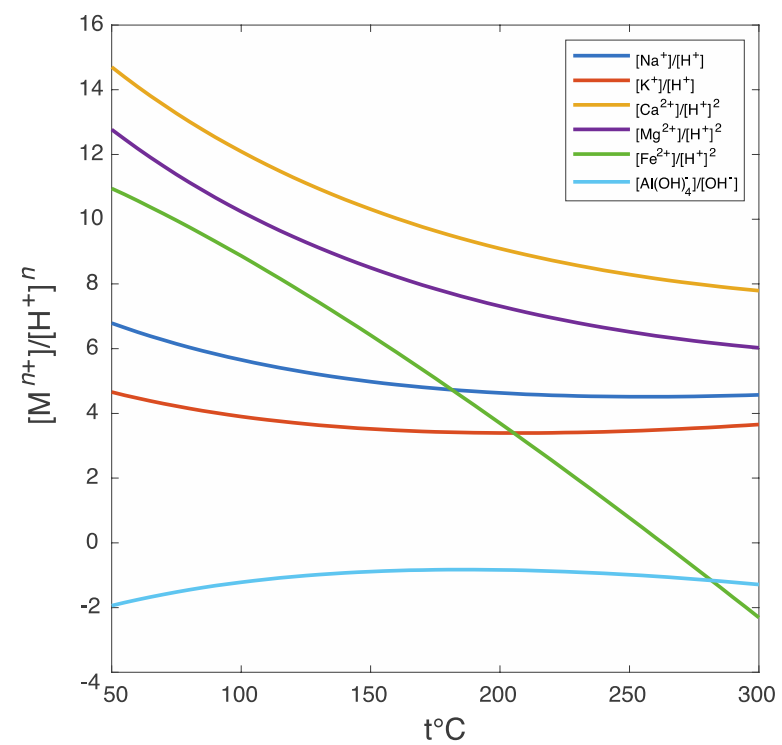


Figure 4. Effect of temperature on $\left[\mathrm{M}^{n+}\right] /\left[\mathrm{H}^{+}\right]^{n}$ ratios in hydrothermal fluids. Increased acid425 ity of the fluids at high temperature overwhelms the effect of temperature on equilibrium constants. Equations established on Iceland geothermal fields and taken from Arnorsson et al. (1983). These equations incorporate the effect of ionic strength. Water-rock temperature interaction (weathering) at low temperatures is a proton sink in contrast to high-temperature processes which produce low-pH solutions.

430 An additional proton source is the inorganic oxidation of $\mathrm{Fe}^{2+}$ to $\mathrm{Fe}^{3+}$, regardless of the reaction involved. Braterman et al. $(1983 ; 1984)$ pointed out that dissolved $\mathrm{Fe}^{2+}$, partially hydrolyzed as $\mathrm{Fe}(\mathrm{OH})^{+}$, absorbs UV radiation in the $200-400 \mathrm{~nm}$ range and forms $\mathrm{FeO}(\mathrm{OH})$ :

$$
\mathrm{Fe}^{2+}+2 \mathrm{H}_{2} \mathrm{O} \rightarrow \mathrm{FeO}(\mathrm{OH})+\frac{1}{2} \mathrm{H}_{2}+2 \mathrm{H}^{+}
$$

Likewise, Thibon et al. (2019) observed that $\mathrm{CO}_{2}$ is reduced to $\mathrm{CH}_{4}$ by dissolved $\mathrm{Fe}^{2+}$ accord435 ing to the magnetite-forming reaction:

$\frac{1}{8} \mathrm{CO}_{2}+\frac{3}{2} \mathrm{Fe}^{2+}+\frac{7}{4} \mathrm{H}_{2} \mathrm{O} \leftrightharpoons \frac{1}{2} \mathrm{Fe}_{3} \mathrm{O}_{4}+\frac{1}{8} \mathrm{CH}_{4}+3 \mathrm{H}^{+}$

The ferrihydrite- $\mathrm{Fe}^{2+}$ equilibrium has the same effect:

$\frac{1}{8} \mathrm{CO}_{2}+\mathrm{Fe}^{2+}+\frac{7}{4} \mathrm{H}_{2} \mathrm{O} \leftrightharpoons \frac{1}{8} \mathrm{CH}_{4}+\mathrm{FeO}(\mathrm{OH})+2 \mathrm{H}^{+}$

Consequences of the charge balance on electrolyte concentration can be simply described 440 using Shikazono's (1978) equations. The water/rock reactions listed above, or alternative equivalent reactions, can all be written in the form of $\left[\mathrm{M}^{n+}\right] /\left[\mathrm{H}^{+}\right]^{n}=K_{\mathrm{M}}(T)$, where $\mathrm{M}$ stands for any metal and $K$ for equilibrium constants. For the sake of simplicity, activity coefficients and complexation constants have been ignored. The charge balance can be written at the first order as

$445 K_{\mathrm{Na}}\left[\mathrm{H}^{+}\right]+K_{\mathrm{K}}\left[\mathrm{H}^{+}\right]+2 K_{\mathrm{Mg}}\left[\mathrm{H}^{+}\right]^{2}+2 K_{\mathrm{Fe}}\left[\mathrm{H}^{+}\right]^{2}+2 K_{\mathrm{Ca}}\left[\mathrm{H}^{+}\right]^{2}+\cdots=\mathrm{Alk}+\left[\mathrm{Cl}^{-}\right] \approx\left[\mathrm{Cl}^{-}\right](16)$ 
(Arnórsson et al., 1983). For set eruption temperature and chlorinity, greenschist facies mineral assemblages actually buffer the composition of hydrothermal vent solutions through geologic time. The compositions calculated for hydrothermal fluids (Bowers and Taylor, 1985; Michard, 1982) compare reasonably well with those measured on the samples collected on the East Pacific Rise. Although the fluxes associated with the loss of seawater into the midocean ridge depends on how well seawater composition is known, the hydrothermal inputs are unlikely to have substantially changed through time under the effect of parameters other than seawater chlorinity.

An important outcome of Eqn.6 is the relationship:

$d \log \left[M^{n+}\right]=n d \log \left[\mathrm{Cl}^{-}\right]$

460 where $n=1$ for $\left[\mathrm{H}^{+}\right],\left[\mathrm{Na}^{+}\right]$, and $\left[\mathrm{K}^{+}\right]$, and $n=2$ for $\left[\mathrm{Mg}^{2+}\right],\left[\mathrm{Ca}^{2+}\right]$, and $\left[\mathrm{Fe}^{2+}\right]$, etc (Shikazono, 1978). In other words, $\left[\mathrm{Cl}^{-}\right]$variations strongly affect the relative abundances of heterovalent cations. In addition to the standard $\mathrm{Na} / \mathrm{K}$ geothermometer, the $\left[\mathrm{Fe}^{2+}\right] /\left[\mathrm{K}^{+}\right]$ratio may be a good temperature diagnostic. Arnórsson et al. (1983) show that, on the condition of no brine separation, heterovalent ratios such a $[\mathrm{Na}]^{2} /[\mathrm{Mg}]$ and $[\mathrm{Al}]^{2} /[\mathrm{Mg}]$ may be good prox465 ies of the chlorinity of hydrothermal fluids and therefore of seawater (Arnórsson et al., 1983) (Figure 5). How these chlorinity proxies are imprinted on the metamorphic rock record is at this stage the major stumbling block. 
1

2

3

4

5

6

9

10

11

12

13

14

15

16

17

18

19

20

21

22

23

24

25

26

27

28

29

30

31

32

33

34

35

36

37

38

39

40

41

42

43

44

45

46

47

48

49

50

51

52

53

54

55

56

57

58

59

60

61

62

63

64

65
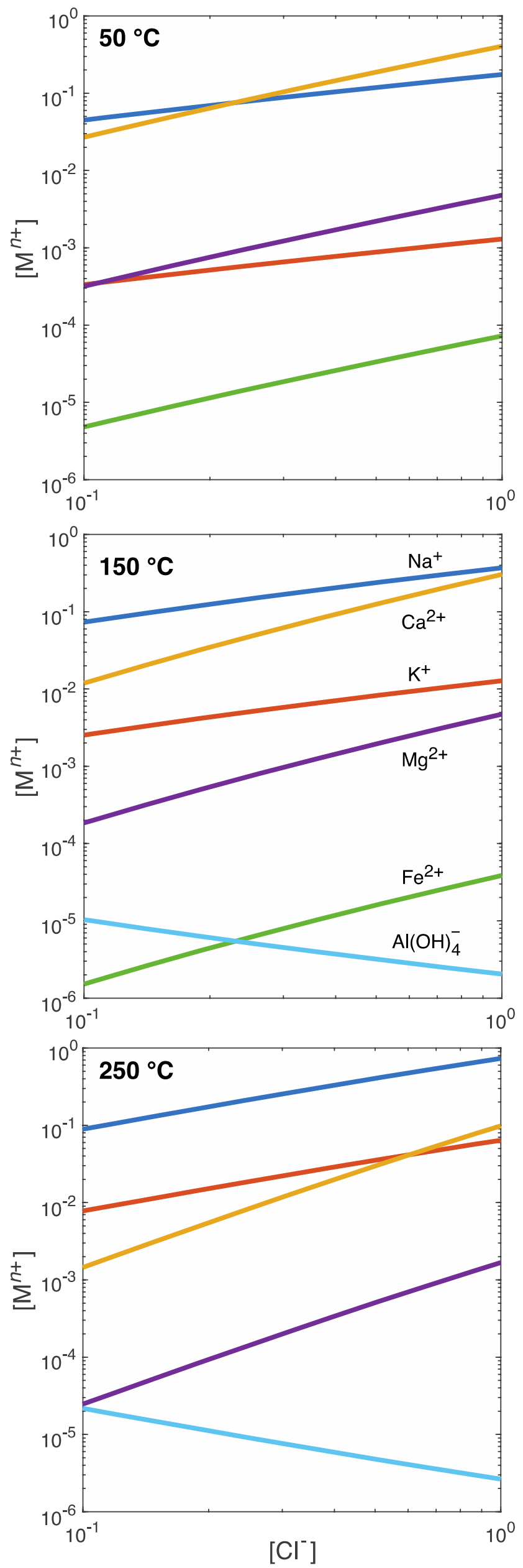
Figure 5. Effect of chlorine on the composition of solutions calculated from Arnorsson et

470 al. 's (1983) equations. Units in mol $L^{-1}(M)$. This plot illustrates the potential of using hydrothermal fluid reconstructions and ratios of heterovalent cations to infer the chlorinity of ancient seawater.

\subsection{The electron balance}

Ever since the GOE, $\mathrm{H}_{2} \mathrm{O}$ and $\mathrm{O}_{2}$ have been the dominant redox couple of the 475 ocean/atmosphere system. Not so, however, on the early Earth devoid of oxygen. The geochemical, pedological, and sedimentological features used to document the low level of oxygen in the pre-GOE atmosphere are multiple and often consistent (see (Lyons et al., 2014) for a review), but the strongest evidence so far supporting lack of ozone and therefore low $\mathrm{O}_{2}$ levels in the Archean atmosphere comes from the photolytic fractionation of sulfur isotopes 480 (Farquhar et al., 2000). In the absence of $\mathrm{O}_{2}$, the existence of large amounts of ferric iron precipitated from $\mathrm{Fe}^{2+}$-rich seawater requires the availability of abundant electron acceptors and the options are few.

One solution to this issue is the coupling of iron oxidation with biological activity (Holland, 1973):

$4854 \mathrm{Fe}^{2+}+\mathrm{HCO}_{3}^{-}+10 \mathrm{H}_{2} \mathrm{O} \leftrightharpoons \mathrm{CH}_{2} \mathrm{O}+4 \mathrm{Fe}(\mathrm{OH})_{3}+7 \mathrm{H}^{+}$

The very low abundance of $\mathrm{P}$ in BIF, however, argues against BIF precipitation being fueled by biological activity (Klein and Beukes, 1989; Thibon et al., 2019).

A second solution is the photolytic oxidation of $\mathrm{Fe}^{2+}$ mentioned above. However, as noted before (Braterman et al., 1983; Braterman et al., 1984; Konhauser et al., 2007) and regardless 490 of the fate of hydrogen gas, iron photolysis quickly brings the $\mathrm{pH}$ of seawater down to values at which the reaction direction is reverted and photooxidation stops. An additional difficulty is that this reaction only takes place in the uppermost layers of the ocean. Ferrous iron must, 
therefore, be replenished by deep water rising to the surface, a mechanism unlikely to be efficient.

495 These problems led Thibon et al. (2019) to suggest that the electron liberated by oxidation of seawater $\mathrm{Fe}^{2+}$ is used to reduce $\mathrm{HCO}_{3}^{-}$, and eventually atmospheric $\mathrm{CO}_{2}$, to methane. Under such conditions, the $\mathrm{CH}_{4} / \mathrm{CO}_{2}$ ratio of the atmosphere is buffered by dissolved $\mathrm{Fe}^{2+}$ and coexisting $\mathrm{Fe}^{3+}$-bearing sedimentary minerals (Figure 6), magnetite or any other oxyhydroxide. The coefficients of this equation show that, at the interface between the atmosphere and seawater buffered by magnetite, the $\mathrm{CH}_{4} / \mathrm{CO}_{2}$ ratio is extremely sensitive to both $\left[\mathrm{Fe}^{2+}\right]$ and $\mathrm{pH}$. The $\mathrm{CH}_{4} / \mathrm{CO}_{2}$ ratio of the atmosphere in equilibrium with magnetite and $\mathrm{Fe}^{2+}$ increases with increasing $\mathrm{pH}$ and $\left[\mathrm{Fe}^{2+}\right]$. Zahnle et al. (2019) show that $5000 \mathrm{ppmv} \mathrm{CH}_{4}$ or more in the atmosphere provide an adequate source of $\mathrm{H}^{+}$capable of ionizing Xe and force its escape, thereby accounting for the remarkable isotopic fractionation of this heavy rare gas. An equimolar $\mathrm{CH}_{4}-\mathrm{CO}_{2}$ atmosphere (Haqq-Misra et al., 2008) requires $\mathrm{pH}$ of 5.6, 6.6, and 7.6 for $\left[\mathrm{Fe}^{2+}\right]=10^{-2}, 10^{-4}$, and $10^{-6} \mathrm{M}$, respectively (Figure 6).

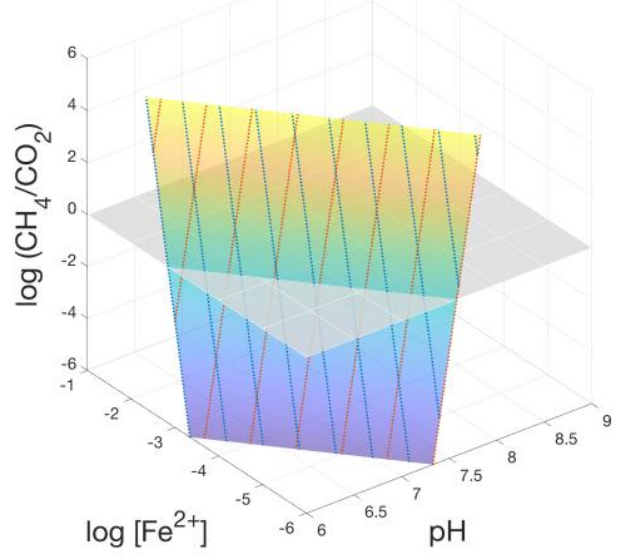


Figure 6. The $\mathrm{CH}_{4} / \mathrm{CO}_{2}$ ratio of the atmosphere in equilibrium with magnetite and $\mathrm{Fe}^{2+}$ for different oceanic values of $\mathrm{Fe}^{2+}$ and $\mathrm{pH}$. Red lines represent constant $\left[\mathrm{Fe}^{2+}\right]$ values and blue lines constant $\mathrm{pH}$ values.

The outcome is essentially unchanged if hematite $\left(\mathrm{Fe}_{2} \mathrm{O}_{3}\right)$ or ferrihydrite or $\mathrm{Fe}_{2} \mathrm{O}_{3} \cdot \mathrm{xH}_{2} \mathrm{O}$ are preferred to magnetite, i.e. the conditions for an equimolar $\mathrm{CH}_{4}-\mathrm{CO}_{2}$ atmosphere are not drastically different from those required for magnetite. Using thermodynamic data at $25^{\circ} \mathrm{C}$ (Anderson, 2005; Lemire et al., 2013), the following relationships are obtained:

$515 \mathrm{pH}=6.0-\frac{1}{2} \log \left[\mathrm{Fe}^{2+}\right]$

for magnetite, and

$\mathrm{pH}=5.7-\frac{1}{2} \log \left[\mathrm{Fe}^{2+}\right]$

for ferrihydrite. These equations compare well with that of greenalite saturation at $\log \left[\mathrm{SiO}_{2}\right]$ $=-2.760($ see Fig. 12 in Tosca et al. (2016)):

$520 \mathrm{pH}=5.5-\frac{1}{2} \log \left[\mathrm{Fe}^{2+}\right]$

Seawater with a pH of $\sim 7$ can easily host $\mathrm{Fe}^{2+}$ at the millimolar concentration levels proposed by Thibon et al. (2019). The reason why equations $19-21$ are so similar is that the ratio $\left[\mathrm{Fe}^{2+}\right] /\left[\mathrm{H}^{+}\right]^{2}$ only depends on temperature regardless of the nature of the primary mineral precipitating out of seawater to form the BIF precursors.

\section{4. Implications for some of the pre-GOE geochemical cycles}

Pre-GOE carbonates are scarce and have undergone diagenetic and metamorphic processes, often to a severe extent (see above). Given the lack of sulfate in the contemporaneous seawater, the ${ }^{87} \mathrm{Sr} /{ }^{86} \mathrm{Sr}$ record by pre-GOE samples of barite, a mineral often perceived as an alternative marker of the marine environment (e.g., (Satkoski et al., 2017), is more ambiguous than the record of sedimentary carbonates. The timing of the divergence of the marine $\mathrm{Sr}$ 
isotope record from the mantle evolution curve is therefore still an open question. Nevertheless, Derry and Jacobsen (1988) suggested that Sr isotopes in chemical sediments are best explained by a higher hydrothermal to river water flux ratio during the Early Proterozoic. Likewise, rare-earth elements and $\mathrm{Sr}$ isotopes in $2.52 \mathrm{Ga}$ old Campbellrand carbonates were 535 interpreted by a weaker continental erosion flux with respect to hydrothermal fluxes than today (Kamber and Webb, 2001).

\subsection{Chlorine}

Seawater composition clearly changes with the evolving composition of the atmosphere and with growing continental expanses. It also responds to changing concentrations of chlorine 540 (Coogan et al., 2019), an element that has so far largely eluded extensive observation and well-constrained modeling (Eggenkamp, 2014; Holland, 1984). An original estimate of the chlorinity of Archean seawater was proposed by Marty et al. (2018) as an end-member of the correlation between $\mathrm{Cl} /{ }^{36} \mathrm{Ar}$ and $\mathrm{K} /{ }^{36} \mathrm{Ar}$ in fluids extracted from a single inclusion in quartz. These fluids share many geochemical characteristics with Red Sea brines (Schmidt et al.,

545 2015). The $\mathrm{Cl} / \mathrm{K}$ ratio of the most diluted sample ( 54$)$ is indistinguishable from the ratio in modern seawater. The error bar due to uncertainties on equilibration temperature is, however, no better than a factor of two for $\left[\mathrm{Cl}^{-}\right]$, which translates into a fourfold uncertainty on $\left[\mathrm{Mg}^{2+}\right]$, $\left[\mathrm{Ca}^{2+}\right]$, and $\left[\mathrm{Fe}^{2+}\right]$. More worrisome is the observation that these fluid inclusions contain fair amounts of unsupported ${ }^{40} \mathrm{Ar}$. As suggested by the authors, ${ }^{40} \mathrm{Ar}$ excess may have been intro550 duced from the country rocks. A minimum value of the low-salinity component ${ }^{40} \mathrm{Ar} /{ }^{36} \mathrm{Ar}$ can be inferred from the intercept of the ${ }^{40} \mathrm{Ar} /{ }^{36} \mathrm{Ar} v \mathrm{Ks} /{ }^{36} \mathrm{Ar}$ array. The alignment is good $\left(r^{2}=0.99\right)$ but the intercept is far too high $\left({ }^{40} \mathrm{Ar} /{ }^{36} \mathrm{Ar}>2800\right)$ for original equilibration of this component with the atmosphere. The approach is nevertheless very promising, and provided this problem can be tackled with appropriate geochemical and mineralogical tools, the un555 known that is ancient seawater chlorinity may be within reach. 


\subsection{Protons}

The oceanic inputs correspond to the high-temperature fluids of mid-ocean ridge hydrothermal systems and other volcanic sources and the precipitation of magnetite or ferrihydrite in $\mathrm{BIF}$, whereas the main output is accounted for by the low-temperature alteration on the flanks 560 of mid-ocean ridges. Low-temperature exchange between seawater and the oceanic crust is poorly constrained simply because reliable proxies are rare. Most pre-GOE samples were profoundly altered at different times and the complex overprinting of weathering, diagenesis, alteration, and metamorphism is difficult to disentangle. A robust statement emerges, however, from the previous discussion: $\left[\mathrm{Cl}^{-}\right]$is the gatekeeper of charge balance and equilibrium 565 constants at high temperatures favor preferential release of protons and increase $\left[\mathrm{H}^{+}\right]$by orders of magnitude in fluids relative to the increase of any other cations. On the input side, the runoff was smaller in pre-GOE times than today due to scant land surfaces and low atmospheric $P_{\mathrm{CO} 2}$ and therefore had a proportionately smaller neutralizing capacity. The seawater $\mathrm{pH}$ must, therefore, have been lower than today and the chlorinity higher. The effect is par570 ticularly severe since, from equation 17 , a decrease of one unit of $\mathrm{pH}$ in high-temperature hydrothermal fluids requires a $\left[\mathrm{Cl}^{-}\right]$increase by a factor of 10 .

\subsection{Electrons}

Precipitation of $\mathrm{Fe}^{3+}$-bearing minerals (ferrihydrite and magnetite) liberates electrons that must be removed either by producing organic material (Holland, 1973) or by the reduction of 575 volcanic $\mathrm{CO}_{2}$ into $\mathrm{CH}_{4}$, thus liberating more protons (equations $\left.13-15\right) . \mathrm{Fe}^{2+}$ solubility in seawater increases with decreasing $\mathrm{pH}$.

\subsection{Iron}

Contrary to the modern ocean in which ferric iron is insoluble and seawater is devoid of iron, $\mathrm{Fe}^{2+}$ was massively transferred from the low-temperature sites of water-rock interaction to 
580 the high-temperature hydrothermal vent fluids at ridge crests and injected into the ocean. In1 jection of hydrothermal fluids into the ocean was suggested on a global scale by Derry and Jacobsen (1988) and the record of mixing events demonstrated through the rare-earth element patterns of late Archean Campbellrand carbonates (Kamber and Webb, 2001). Iron is removed, after partial oxidation, by BIF precipitation and, to a lesser extent, traps runoff car585 bonate as siderite and ankerite on continental shelfs. 


\subsection{Sodium and potassium}

The higher $\left[\mathrm{Na}^{+}\right] /\left[\mathrm{H}^{+}\right]$and $\left[\mathrm{K}^{+}\right] /\left[\mathrm{H}^{+}\right]$ratios of hydrothermal fluids at low temperature relative to high-temperature fluids essentially reflect their higher $\mathrm{pH}$ and not necessarily a net loss of alkali elements. High-temperature hydrothermal vents from mid-ocean ridges add excess $\mathrm{K}^{+}$ 590 to the ocean (Edmond et al., 1979b) which, in accordance with mineralogical observations, is removed by low-temperature alteration (Alt et al., 1996; German and Von Damm, 2006; Magenheim et al., 1995). Because the Na-K substitution is isovalent, the $\mathrm{Na} / \mathrm{K}$ ratio is expected to be dominated by its dependence on temperature. This is illustrated by the broad acceptance of Na-K thermometry of hydrothermal solutions (Fournier and Truesdell, 1973;

595 Giggenbach, 1988). Sodium itself in hydrothermal fluids has not received much attention, presumably because of its very long residence time in seawater (Broecker and Peng, 1982). Today, $\mathrm{Na}^{+}$is slightly depleted in both low- and high-temperature hydrothermal fluids with respect to seawater (Elderfield and Schultz, 1996; German and Von Damm, 2006; Von Damm, 1990a), a deficit compensated for by runoff. In an ancient world with little subaerial 600 expanses, the Na cycle would be out of balance, which may indicate that the metamorphic assemblage reacting with hydrothermal fluids could be very different from its modern equivalent or that a diagenetic input may have been overlooked. Ancient seawater may have had less Na and more divalent $\mathrm{Ca}$ and Fe.

\subsection{Magnesium and calcium}

605 A recent discussion of the global modern cycle of these elements can be found in Higgins and Schrag(2015). From the perspective taken here, the fluxes of double-charged elements between high- and low-temperature hydrothermal systems should be larger than for singlecharged elements. Magnesium is the most intriguing of all the major elements, since it is efficiently removed from seawater at temperatures in excess of $50^{\circ} \mathrm{C}$ and does not seem to have 610 any obvious major source other than runoff. In hydrothermal vents, the Ca-Mg substitution is 
also isovalent. The $\mathrm{Ca} / \mathrm{Mg}$ ratio is more scattered that the $\mathrm{Na} / \mathrm{K}$ ratio (Fournier and Truesdell, 1973; Giggenbach, 1988), most likely as a result of carbonatization and the production of clay minerals. A minor source may be submarine felsic intra-oceanic arc volcanics (de Ronde et al., 2019), which have been shown to have lost most of their Mg, but the scarcity of these 615 rocks and their rather low initial $\mathrm{Mg}$ abundance is unlikely to make them a strong oceanic source. Because of smaller continental inputs, Archean seawater must have been more depleted in $\mathrm{Mg}$ than its modern equivalent. Magnesium in sediments may be an alternative measure of the surface of continents above sea level. Likewise, high-temperature hydrothermal alteration adds $\mathrm{Ca}^{2+}$ excess to the ocean. This excess is removed in part by low620 temperature hydrothermal reactions, in part by carbonate precipitation on continental shelves. High chlorinity favors low $\mathrm{pH}$ and high $\mathrm{Ca} / \mathrm{Na}$ ratios (Figure 5) in hydrothermal fluids, which may help resolve the imbalance of the sodium cycle.

\subsection{Phosphorus}

Phosphorus is taken up by both hydrothermal vents from mid-ocean ridges and low625 temperature alteration of the oceanic crust. Alt et al. (1996) find no measurable downcore variation of $\mathrm{P}_{2} \mathrm{O}_{5}$ in DSDP Hole 504B. Gernon et al. (2016) argue that palagonitization of volcanic glass leads to release of phosphorus into seawater, but Kruber et al.'s data (2008) on the most immobile elements in glasses from the Mohns Ridge and associated palagonite clearly show that this assessment is incorrect. The $\mathrm{P}_{2} \mathrm{O}_{5} / \mathrm{TiO}_{2}, \mathrm{P}_{2} \mathrm{O}_{5} / \mathrm{MnO}, \mathrm{P}_{2} \mathrm{O}_{5} / \mathrm{Y}_{2} \mathrm{P}_{2} \mathrm{O}_{5} / \mathrm{REE}$, 630 and $\mathrm{P}_{2} \mathrm{O}_{5} /$ Th in paragonite are $150,34,30,60$, and $12 \%$ higher, respectively, than in glass. This requires $\mathrm{P}$ gain, not loss, during glass palagonitization.

\subsection{Alkalinity}

High-temperature hydrothermal fluids bring zero to negative alkalinity to the modern ocean (Von Damm, 1990a), while acidity fluxes from low-temperature upper ocean crust alteration 
635 do not balance riverine fluxes of alkalinity(Spivack and Staudigel, 1994). To a large extent, alkalinity fluctuations therefore reflect the effect of weathering and the surface area of continental surfaces. $\mathrm{pH}$ and seawater alkalinity control atmospheric $P_{\mathrm{CO} 2}$ through one of the standard equations of the carbonate system (Broecker and Peng, 1982; Zeebe and WolfGladrow, 2001):

$P_{\mathrm{CO}_{2}}=\frac{A l k}{K_{1} k_{\mathrm{CO} 2}} \times \frac{\left[\mathrm{H}^{+}\right]^{2}}{\left[\mathrm{H}^{+}\right]+2 K_{2}}$

in which $K_{1}$ and $K_{2}$ are the dissociation constants of carbonic acid, and $k_{\mathrm{CO} 2}$ the $\mathrm{CO}_{2}$ solubility constant in seawater. For ancient seawater, the two conditions used by Halevy and Bachan (2017) who assumed both a significant atmospheric $P_{\mathrm{CO}_{2}}$ and carbonate saturation to infer the evolution of seawater $\mathrm{pH}$ through geological times over-constrain the system. The pre-GOE 645 continental input of alkalinity must have been small compared to its modern equivalent, while mid-ocean ridges released abundant protons. In agreement with conclusions from the $\mathrm{Fe}^{2+} /$ magnetite equilibrium, seawater alkalinity must have been small or even negative. The pre-GOE alkalinity balance not only explains, but requires the scarcity of carbonates in the pre-GOE geological record, which is consistent with the rather small fluxes of detrital mate650 rial represented by mudstones. Morse and Mackenzie (1998) concluded, however, that the alkalinity of the Archean ocean was higher than in the Phanerozoic. Their conclusion was based on a high atmospheric $P_{\mathrm{CO} 2}$, on the assumption that the surface of the ocean was saturated in carbonates, on assumed high seawater $\left[\mathrm{Na}^{+}\right]$and $\left[\mathrm{Cl}^{-}\right]$, and unlimited $\mathrm{P}$ availability.

Until the GOE, BIF were the main sedimentary sink of oceanic cations. To a large extent, the 655 removal of Fe added by high-temperature vents through BIF precipitation, plus conversion of $\mathrm{CO}_{2}$ to $\mathrm{CH}_{4}$, played during the Archean the role that carbonates play in the modern world for removing excess positive charges and therefore for controlling altogether the alkalinity of Archean seawater. 


\section{Conclusions}

660 The main points arrived at in this work can be summarized as follows:

1. Dissolved chlorine is the gatekeeper of pre-GOE charge balance in seawater. Several indices point to seawater $\left[\mathrm{Cl}^{-}\right]$being higher and the $\mathrm{pH}$ lower in the Archean than today but evidence is still tenuous.

2. Prior to GOE, BIF were the main sedimentary sink of seawater cations, a role played in the modern ocean by carbonate sedimentation.

3. The chemistry of pre-GOE seawater differs from modern seawater by the presence of soluble $\mathrm{Fe}^{2+}$, which may have permitted the reduction of $\mathrm{HCO}_{3}^{-}$to methane.

4. The very low P contents of BIF is inconsistent with a control of iron oxidation by biological activity.

5. The timing of the rise of continents above sea level indicated by the seawater ${ }^{87} \mathrm{Sr} /{ }^{86} \mathrm{Sr}$ record depends on which genetic significance is assigned to pre-GOE barite in a sulfate-free ocean.

6. The low P contents of ancient sediments and the Sr isotope record of carbonates indicate that Archean subaerial expanses occupied about 7\% of the Earth's surface prior to the GOE, i.e. about $20 \%$ of their modern equivalent. The reliability of these estimates would benefit from better understanding of P distribution among sedimentary sinks and diagenetic and metamorphic overprinting. Smaller subaerial exposures imply that the proton sinks and alkalinity sources of weathering were much weaker than today. As a consequence, seawater had a lower $\mathrm{pH}$ and therefore less carbonate and less alkalinity.

7. The $\mathrm{Na}$ and $\mathrm{Mg}$ cycles in the pre-GOE ocean seem to have been out of balance and require the identification of missing inputs. 
8. Seawater iron concentration is controlled by its $\left[\mathrm{Fe}^{2+}\right] /\left[\mathrm{H}^{+}\right]^{2}$ ratio, temperature, and chlorinity. Lower $\mathrm{pH}$ rendered $\mathrm{Fe}^{2+}$ more soluble than in the modern ocean. Buffering of seawater $\left[\mathrm{Fe}^{2+}\right]$ by ferrihydrite, magnetite, or greenalite from $\mathrm{Fe}^{2+}$-rich seawater is consistent with methane being a major component of the ancient terrestrial atmosphere. This new reaction pathway for the formation of Paleoproterozoic BIF helps resolve the problem of the formation of Archean BIF, which cannot be attributed to extensive $\mathrm{O}_{2}$ production by biological activity. Seawater $\mathrm{Fe}^{2+}$ and BIF played the same role as $\mathrm{Ca}^{2+}$ and $\mathrm{CaCO}_{3}$ in the modern ocean.

\section{Acknowledgements}

This work has had a long history of review and we would like to thank those reviewers who found some merit to an approach of Archean seawater chemistry inspired largely by the work of John Edmond and Wally Broecker. As these two giants curiously seem to have fallen into near oblivion by the Archean sedimentary geochemistry community, the present work is a plea for bridging the gap with modern marine chemistry. We thank one (anonymous) reviewer in particular and Editor Balz Kamber for courteous and insightful reviews, remarks, and suggestions. Laurent Charlet and Anne-Marie Aucour are thanked for checking our equilibrium calculations and Bernard Marty for comments on Archean seawater chlorinity. 


\section{References}

Albarède, F., Michard, A., Minster, J., Michard, G., 1981. 87Sr/86Sr ratios in hydrothermal waters and deposits from the East Pacific Rise at 21 N. Earth and Planetary Science Letters, 55(2): 229-236.

Alt, J.C. et al., 1996. 34. Hydrothermal alteration of a section of upper oceanic crust in the Eastern Equatorial Pacific: a synthesis of results from site 504 (DSDP LEGS 69, 70, and 83, and ODP LEGS 111, 137,140, and 148), Proceedings of the Ocean Drilling Program, scientific results.

710 Alt, J.C., Teagle, D.A., 1999. The uptake of carbon during alteration of ocean crust. Geochimica et Cosmochimica Acta, 63(10): 1527-1535.

Anderson, G.M., 2005. Thermodynamics of natural systems. Cambridge University Press.

Arndt, N., 1999. Why was flood volcanism on submerged continental platforms so common in the Precambrian? Precambrian Research, 97(3-4): 155-164.

715 Arnórsson, S., Gunnlaugsson, E., Svavarsson, H., 1983. The chemistry of geothermal waters in Iceland. II. Mineral equilibria and independent variables controlling water compositions. Geochimica et Cosmochimica Acta, 47(3): 547-566.

Baturin, G.N., 2003. Phosphorus cycle in the ocean. Lithology and Mineral Resources, 38(2): 101-119.

720 Becker, T.W., Conrad, C.P., Buffett, B., Müller, R.D., 2009. Past and present seafloor age distributions and the temporal evolution of plate tectonic heat transport. Earth and Planetary Science Letters, 278(3-4): 233-242.

Berner, E.K., Berner, R.A., 2012. Global Environment: Water, Air, and Geochemical Cycles. Princeton University Press.

725 Beukes, N.J., Klein, C., Kaufman, A.J., Hayes, J., 1990. Carbonate petrography, kerogen distribution, and carbon and oxygen isotope variations in an early Proterozoic transition from limestone to iron-formation deposition, Transvaal Supergroup, South Africa. Economic geology and the bulletin of the Society of Economic Geologists, 85(4): 663-690.

730 Bindeman, I. et al., 2018. Rapid emergence of subaerial landmasses and onset of a modern hydrologic cycle 2.5 billion years ago. Nature, 557(7706): 545-548.

Bischoff, J.L., Rosenbauer, R.J., 1985. An empirical equation of state for hydrothermal seawater (3.2 percent $\mathrm{NaCl}$ ). American Journal of Science, 285(8): 725-763.

Bjerrum, C.J., Canfield, D.E., 2002. Ocean productivity before about $1.9 \mathrm{Gyr}$ ago limited by phosphorus adsorption onto iron oxides. Nature, 417: 159-162.

Blanc, P. et al., 2015. A generalized model for predicting the thermodynamic properties of clay minerals. American journal of science, 315(8): 734-780.

Bowers, T.S., Taylor, H.P., 1985. An integrated chemical and stable-isotope model of the origin of midocean ridge hot spring systems. Journal of Geophysical Research: Solid Earth, 90(B14): 12583-12606.

Braterman, P.S., Cairns-Smith, A.G., Sloper, R.W., 1983. Photo-oxidation of hydrated $\mathrm{Fe} 2+$ - significance for banded iron formations. Nature, 303(5913): 163.

Braterman, P.S., Cairns-Smith, A.G., Sloper, R.W., Truscott, T.G., Craw, M., 1984. Photooxidation of iron (II) in water between $\mathrm{pH} 7.5$ and 4.0. Journal of the Chemical Society, Dalton Transactions(7): 1441-1445.

Broecker, W.S., Peng, T.-H., 1982. Tracers in the Sea. Eldigio Press, Palisades, N.Y., 690 pp.

Buick, R., Rasmussen, B., Krapez, B., 1998. Archean oil: evidence for extensive hydrocarbon generation and migration 2.5-3.5 Ga. AAPG bulletin, 82(1): 50-69. 
Buick, R. et al., 1995. Record of emergent continental crust 3.5 billion years ago in the Pilbara Craton of Australia. Nature, 375(6532): 574-577.

Cameron, E., Baumann, A., 1972. Carbonate sedimentation during the Archean. Chemical Geology, 10(1): 17-30.

Campbell, I.H., Allen, C.M., 2008. Formation of supercontinents linked to increases in atmospheric oxygen. Nature Geoscience, 1(8): 554-558.

755 Coogan, L.A., Seyfried, W.E., Pester, N.J., 2019. Environmental controls on mid-ocean ridge hydrothermal fluxes. Chemical Geology, 528: 119285.

Cook, P.J., Cook, P.J., Shergold, J., 2005. Phosphate deposits of the world: Volume 1: Proterozoic and Cambrian phosphorites, Cambridge University Press.

Craig, H., Gordon, L., Horibe, Y., 1963. Isotopic exchange effects in the evaporation of water: 1. Low-temperature experimental results. Journal of Geophysical Research, 68(17): 5079-5087.

de Ronde, C.E., Humphris, S.E., Höfig, T.W., 2019. International Ocean Discovery Program Expedition 376 Preliminary Report.

Derry, L.A., 2010. A burial diagenesis origin for the Ediacaran Shuram-Wonoka carbon isotope anomaly. Earth and Planetary Science Letters, 294(1-2): 152-162.

Derry, L.A., Jacobsen, S.B., 1988. The Nd and Sr isotopic evolution of Proterozoic seawater. Geophysical Research Letters, 15(4): 397-400.

Edgar, K.M., Anagnostou, E., Pearson, P.N., Foster, G.L., 2015. Assessing the impact of diagenesis on $\delta^{11} \mathrm{~B}, \delta^{13} \mathrm{C}, \delta^{18} \mathrm{O}, \mathrm{Sr} / \mathrm{Ca}$ and $\mathrm{B} / \mathrm{Ca}$ values in fossil planktic foraminiferal calcite. Geochimica et Cosmochimica Acta, 166: 189-209.

Edmond, J.M., Corliss, J.B., Gordon, L.I., 1979a. Ridge Crest-Hydrothermal Metamorphism at the Galapagos Spreading Center and Reverse Weathering. In: Talwani, M., Harrison, C.G., Hayes, D.E. (Eds.), Deep drilling results in the Atlantic Ocean: ocean crust. American Geophysical Union, Wasington D.C., pp. 383-390.

775 Edmond, J.M. et al., 1979b. Ridge crest hydrothermal activity and the balances of the major and minor elements in the ocean: The Galapagos data. Earth Planet. Sci. Letters, 46(1): 1-18.

Eggenkamp, H., 2014. The geochemistry of stable chlorine and bromine isotopes. Springer.

Elderfield, H., Schultz, A., 1996. Mid-ocean ridge hydrothermal fluxes and the chemical composition of the ocean. Annual Review of Earth and Planetary Sciences, 24(1): 191-224.

Engel, A.E., Itson, S.P., Engel, C.G., Stickney, D.M., Cray Jr, E.J., 1974. Crustal evolution and global tectonics: a petrogenic view. Geological Society of America Bulletin, 85(6): 843-858.

785 Eriksson, K.A., Simpson, E.L., Mueller, W., 2006. An unusual fluvial to tidal transition in the mesoarchean Moodies Group, South Africa: A response to high tidal range and active tectonics. Sedimentary Geology, 190(1-4): 13-24.

Farquhar, J., Bao, H.M., Thiemens, M., 2000. Atmospheric influence of Earth's earliest sulfur cycle. Science, 289: 756-758.

790 Ferrari, R., Wunsch, C., 2009. Ocean circulation kinetic energy: Reservoirs, sources, and sinks. Annual Review of Fluid Mechanics, 41.

Flament, N., Coltice, N., Rey, P.F., 2008. A case for late-Archaean continental emergence from thermal evolution models and hypsometry. Earth and Planetary Science letters, 275(3-4): 326-336.

795 Flannery, D.T., Allwood, A.C., Van Kranendonk, M.J., 2016. Lacustrine facies dependence of highly 13C-depleted organic matter during the global age of methanotrophy. Precambrian Research, 285: 216-241. 
Fournier, R.O., Truesdell, A.H., 1973. An empirical Na $\square \mathrm{K} \square \mathrm{Ca}$ geothermometer for natural waters. Geochimica et Cosmochimica Acta, 37(5): 1255-1275.

800 Gaillardet, J., Dupré, B., Louvat, P., Allegre, C., 1999. Global silicate weathering and CO2 consumption rates deduced from the chemistry of large rivers. Chemical geology, 159(1-4): 3-30.

Garrels, R., Mackenzie, F.T., 1971. Evolution of sedimentary rocks. Norton New York.

German, C., Von Damm, K., 2006. Hydrothermal processes. Treatise on geochemistry, 6: 181-222.

Gernon, T., Hincks, T., Tyrrell, T., Rohling, E., Palmer, M., 2016. Snowball Earth ocean chemistry driven by extensive ridge volcanism during Rodinia breakup. Nature Geoscience, 9(3): 242-248.

Giggenbach, W.F., 1988. Geothermal solute equilibria. derivation of Na-K-Mg-Ca geoindicators. Geochimica et cosmochimica acta, 52(12): 2749-2765.

Grotzinger, J.P., 1989. Facies and evolution of Precambrian carbonate depositional systems: emergence of the modern platform archetype, Controls on Carbonate Platfonn and Basin Development. SEPM Special Publication No. 44. The Society of Economic Paleontologists and Mineralogists, Broken Arrow, pp. 79-106.

815 Grotzinger, J.P., Kasting, J.F., 1993. New constraints on Precambrian ocean composition. The Journal of Geology, 101(2): 235-243.

Halevy, I., Bachan, A., 2017. The geologic history of seawater pH. Science, 355(6329): 1069-1071.

Haqq-Misra, J.D., Domagal-Goldman, S.D., Kasting, P.J., Kasting, J.F., 2008. A revised, hazy methane greenhouse for the Archean Earth. Astrobiology, 8(6): 1127-1137.

Hasenclever, J. et al., 2014. Hybrid shallow on-axis and deep off-axis hydrothermal circulation at fast-spreading ridges. Nature, 508(7497): 508-512.

Higgins, J.A., Schrag, D.P., 2015. The Mg isotopic composition of Cenozoic seawater evidence for a link between $\mathrm{Mg}$-clays, seawater $\mathrm{Mg} / \mathrm{Ca}$, and climate. Earth and Planetary Science Letters, 416: 73-81.

Holland, H.D., 1973. The oceans - Possible source of iron in iron-formations. Economic Geology, 68: 1169-1172.

Holland, H.D., 1984. The chemical evolution of the atmosphere and oceans. Princeton University Press.

830 Hurley, P.M., Rand, J.R., 1969. Pre-drift continental nuclei. Science, 164: 1229-1242.

Isson, T.T., Planavsky, N.J., 2018. Reverse weathering as a long-term stabilizer of marine $\mathrm{pH}$ and planetary climate. Nature, 560(7719): 471-475.

Jaffrés, J.B., Shields, G.A., Wallmann, K., 2007. The oxygen isotope evolution of seawater: A critical review of a long-standing controversy and an improved geological water cycle model for the past 3.4 billion years. Earth-Science Reviews, 83(1-2): 83-122.

Jahn, B.-m., Simonson, B.M., 1995. Carbonate PbPb ages of the Wittenoom Formation and Carawine Dolomite, Hamersley Basin, Western Australia (with implications for their correlation with the Transvaal Dolomite of South Africa). Precambrian Research, 72(3): 247-261.

840 Johnson, B.W., Wing, B.A., 2020. Limited Archaean continental emergence reflected in an early Archaean 18O-enriched ocean. Nature Geoscience, 13(3): 243-248.

Kamber, B.S., Tomlinson, E.L., 2019. Petrological, mineralogical and geochemical peculiarities of Archaean cratons. Chemical Geology, 511: 123-151.

Kamber, B.S., Webb, G.E., 2001. The geochemistry of late Archaean microbial carbonate: 845 implications for ocean chemistry and continental erosion history. Geochimica et Cosmochimica Acta, 65(15): 2509-2525. 
Kim, K., Lee, X., 2011. Isotopic enrichment of liquid water during evaporation from water surfaces. Journal of hydrology, 399(3-4): 364-375.

Klein, C., Beukes, N.J., 1989. Geochemistry and sedimentology of a facies transition from limestone to iron-formation deposition in the early Proterozoic Transvaal Supergroup, South Africa. Economic Geology, 84(7): 1733-1774.

Konhauser, K. et al., 2017. Iron formations: A global record of Neoarchaean to Palaeoproterozoic environmental history. Earth-Science Reviews, 172: 140-177.

Konhauser, K.O. et al., 2007. Decoupling photochemical Fe (II) oxidation from shallowwater BIF deposition. Earth and Planetary Science Letters, 258(1-2): 87-100.

Kruber, C., Thorseth, I.H., Pedersen, R.B., 2008. Seafloor alteration of basaltic glass: textures, geochemistry, and endolithic microorganisms. Geochemistry, Geophysics, Geosystems, 9(12).

Kump, L.R., Barley, M.E., 2007. Increased subaerial volcanism and the rise of atmospheric oxygen 2.5 billion years ago. Nature, 448(7157): 1033-1036.

Lemire, R.J. et al., 2013. Chemical thermodynamics of iron-Part 1-Chemical thermodynamics volume 13a, Data Bank.

Leutert, T.J. et al., 2019. Sensitivity of clumped isotope temperatures in fossil benthic and planktic foraminifera to diagenetic alteration. Geochimica et Cosmochimica Acta, 257: 354-372.

Li, Y.-L., Konhauser, K.O., Zhai, M., 2017. The formation of magnetite in the early Archean oceans. Earth and Planetary Science Letters, 466: 103-114.

Lowe, D.R., 1980. Archean sedimentation. Annual Review of Earth and Planetary Sciences, 8(1): 145-167.

870 Lyons, T.W., Reinhard, C.T., Planavsky, N.J., 2014. The rise of oxygen in Earth's early ocean and atmosphere. Nature, 506(7488): 307.

Mackenzie, F.T., Morse, J.W., 1992. Sedimentary carbonates through Phanerozoic time. Geochimica et Cosmochimica Acta, 56(8): 3281-3295.

Magenheim, A.J. et al., 1995. 13. BOREHOLE FLUID CHEMISTRY IN HOLE 504B, LEG 137: FORMATION WATER OR IN-SITU REACTION?, Proceedings of the Ocean Drilling Program, Scientific Results, pp. 141-52.

Majzlan, J., Navrotsky, A., Schwertmann, U., 2004. Thermodynamics of iron oxides: Part III. Enthalpies of formation and stability of ferrihydrite $(\sim \mathrm{Fe}(\mathrm{OH}) 3)$, schwertmannite $(\sim \mathrm{FeO}(\mathrm{OH}) 3 / 4(\mathrm{SO} 4) 1 / 8)$, and $\varepsilon-\mathrm{Fe} 2 \mathrm{O} 3$. Geochimica et cosmochimica acta, 68(5): 1049-1059.

Marshall, J., Ferreira, D., Campin, J.-M., Enderton, D., 2007. Mean climate and variability of the atmosphere and ocean on an aquaplanet. Journal of the Atmospheric Sciences, 64(12): 4270-4286.

Marty, B., Avice, G., Bekaert, D.V., Broadley, M.W., 2018. Salinity of the Archaean oceans from analysis of fluid inclusions in quartz. Comptes Rendus Geoscience, 350(4): 154163.

Michard, G., 1982. Rôle des anions mobiles dans le transport des éléments par les solutions hydrothermales. CR Acad. Sci. Paris, Ser. II, 295: 451-454.

Milliman, J.D., 1993. Production and accumulation of calcium carbonate in the ocean: budget of a nonsteady state. Global Biogeochemical Cycles, 7(4): 927-957.

Morse, J.W., Mackenzie, F.T., 1998. Hadean ocean carbonate geochemistry. Aquatic Geochemistry, 4(3-4): 301-319.

Morteani, G., Ackermand, D., Trappe, J., 2007. Aluminum phosphate in Proterozoic metaquartzites: Implications for the Precambrian oceanic P budget and development of life, Geological Society of America Special Papers 423, 579-592. 
Palmer, M.R., Edmond, J.M., 1989. The strontium isotope budget of the modern ocean. Earth Planet. Sci. Letters, 92: 11-26.

Paul, H.J., Gillis, K.M., Coggon, R.M., Teagle, D.A., 2006. ODP Site 1224: A missing link in the investigation of seafloor weathering. Geochemistry, Geophysics, Geosystems, $7(2)$.

Paytan, A., McLaughlin, K., 2007. The oceanic phosphorus cycle. Chemical reviews, 107(2): 563-576.

Pettijohn, F., 1943. Archean sedimentation. Bulletin of the Geological Society of America, 54(7): 925-972.

905 Ransom, B., Helgeson, H.C., 1994. A chemical and thermodynamic model of aluminous dioctahedral 2: 1 layer clay minerals in diagenetic processes; regular solution representation of interlayer dehydration in smectite. American Journal of Science, 294(4): 449-484.

Reinhard, C.T. et al., 2017. Evolution of the global phosphorus cycle. Nature, 541(7637): 386.

Reymer, A., Schubert, G., 1984. Phanerozoic addition rates to the contiental crust. Tectonics, 3: 63-77.

Ronov, A., 1968. Probable changes in the composition of sea water during the course of geological time 1. Sedimentology, 10(1): 25-43.

915 Ruttenberg, K., 1993. Reassessment of the oceanic residence time of phosphorus. Chemical Geology, 107(3-4): 405-409.

Satkoski, A.M., Fralick, P., Beard, B.L., Johnson, C.M., 2017. Initiation of modern-style plate tectonics recorded in Mesoarchean marine chemical sediments. Geochimica et Cosmochimica Acta, 209: 216-232.

920 Schmidt, M., Al-Farawati, R., Botz, R., 2015. Geochemical classification of brine-filled Red Sea deeps, The Red Sea. Springer, pp. 219-233.

Sclater, J.G., Parsons, B., Jaupart, C., 1981. Oceans and continents: similarities and differences in the mechanisms of heat loss. Journal of Geophysical Research: Solid Earth, 86(B12): 11535-11552.

925 Shikazono, N., 1978. Possible cation buffering in chloride-rich geothermal waters. Chemical Geology, 23(1-4): 239-254.

Sillén, L.G., 1961. The physical chemistry of seawater. Oceanography, 67: 549-581.

Simpson, E.L., Eriksson, K.A., Mueller, W.U., 2012. 3.2 Ga eolian deposits from the Moodies Group, Barberton Greenstone Belt, South Africa: Implications for the origin of first-cycle quartz sandstones. Precambrian Research, 214: 185-191.

Smith, R.S., Dubois, C., Marotzke, J., 2006. Global climate and ocean circulation on an aquaplanet ocean-atmosphere general circulation model. Journal of climate, 19(18): 4719-4737.

Spivack, A.J., Staudigel, H., 1994. Low-temperature alteration of the upper oceanic crust and the alkalinity budget of seawater. Chemical Geology, 115(3-4): 239-247.

Stroncik, N.A., Schmincke, H.-U., 2002. Palagonite-a review. International Journal of Earth Sciences, 91(4): 680-697.

Sumner, D.Y., 1997. Carbonate precipitation and oxygen stratification in late Archean seawater as deduced from facies and stratigraphy of the Gamohaan and Frisco formations, Transvaal Supergroup, South Africa. American Journal of Science, 297(5): 455-487.

Thibon, F. et al., 2019. Dynamics of oceanic iron prior to the Great Oxygenation Event. Earth and Planetary Science Letters, 506: 360-370. 
Thurston, P., Ayer, J., Goutier, J., Hamilton, M., 2008. Depositional gaps in Abitibi greenstone belt stratigraphy: A key to exploration for syngenetic mineralization. Economic Geology, 103(6): 1097-1134.

Tosca, N.J., Guggenheim, S., Pufahl, P.K., 2016. An authigenic origin for Precambrian greenalite: Implications for iron formation and the chemistry of ancient seawater. Bulletin, 128(3-4): 511-530.

950 Van Kranendonk, M.J., Webb, G.E., Kamber, B.S., 2003. Geological and trace element evidence for a marine sedimentary environment of deposition and biogenicity of 3.45 $\mathrm{Ga}$ stromatolitic carbonates in the Pilbara Craton, and support for a reducing Archaean ocean. Geobiology, 1(2): 91-108.

Veizer, J., Compston, W., 1976. 87Sr/86Sr in Precambrian carbonates as an index of crustal evolution. Geochimica et Cosmochimica Acta, 40(8): 905-914.

Von Damm, K., 1990a. Seafloor hydrothermal activity: black smoker chemistry and chimneys. Annual Review of Earth and Planetary Sciences, 18(1): 173-204.

Von Damm, K.L., 1990b. Seafloor hydrothemal activity : black smocker chemistry and chimneys. Annual Review of Earth and Planetary Sciences, 18: 173-204.

960 Von Damm, K.L. et al., 2003. Extraordinary phase separation and segregation in vent fluids from the southern East Pacific Rise. Earth Planet. Sci. Letters, 206(3-4 SU -): 365378.

Walker, J.C. et al., 1983. Environmental evolution of the Archean-early Proterozoic Earth. IN: Earth's earliest biosphere: Its origin and evolution (A84-43051 21-51). Princeton, NJ, Princeton University Press, 1983, p. 260-290.: 260-290.

Wheat, C.G. et al., 2004. Venting formation fluids from deep-sea boreholes in a ridge flank setting: ODP Sites 1025 and 1026. Geochemistry, Geophysics, Geosystems, 5(8).

Wheat, C.G., McManus, J., Mottl, M.J., Giambalvo, E., 2003. Oceanic phosphorus imbalance: Magnitude of the mid-ocean ridge flank hydrothermal sink. Geophysical research letters, 30(17).

Wise, D.U., 1973. Freeboard of continents through time. Memoirs of the Geological Society of America, 132: 87-100.

$\mathrm{Wu}, \mathrm{Z}$. et al., 2016. Occurrences and distribution of "invisible" precious metals in sulfide deposits from the Edmond hydrothermal field, Central Indian Ridge. Ore geology reviews, 79: 105-132.

Wunsch, C., Ferrari, R., 2004. Vertical mixing, energy, and the general circulation of the oceans. Annu. Rev. Fluid Mech., 36: 281-314.

Zahnle, K.J., Gacesa, M., Catling, D.C., 2019. Strange messenger: A new history of hydrogen on Earth, as told by Xenon. Geochimica et Cosmochimica Acta, 244: 56-85.

980 Zeebe, R.E., Wolf-Gladrow, D., 2001. $\mathrm{CO}_{2}$ in seawater: equilibrium, kinetics, isotopes. Gulf Professional Publishing. 


\section{Figure captions}

985 Figure 1. A simple box-model representation of the pre-GOE ocean. Runoff is a first-order input (left), chemical sediments (carbonates and oxyhydroxides) a first-order output (right). Interaction between seawater and the oceanic crust at high (mid-ocean ridge crests) and low (mid-ocean ridge flanks and marine volcanoes) temperature combines outputs of seawater and inputs of hydrothermal fluids. This model can be evaluated for the modern ocean using the numbers in Table 1.

Figure 2. The evolution of phosphorus concentrations in $\sim 8000$ samples of marine sediments from the geological record (Reinhard et al., 2017). The red circles represent the average of the data binned by 100 My slices. The blue shaded area is the $1 \square$ confidence interval. The white dotted line is an exponential fit to the average values. Phosphorus rises continuously by, on average, $34 \%$ per Gy. The GOE $(\sim 2.4 \mathrm{Ga})$ does not seem to be associated with a sharp increase of phosphorus and therefore does not mark a sudden rise of continents above sea level.

Figure 3. Charge balance (alkalinity) in modern seawater compared to what it might have been in the Archean world with only a small proportion of emerged continents. Concentrations for Archean seawater are tentative and are shown for the sake of illustration: lower chlorinity, high $\mathrm{Fe}$ contents, lack of $\mathrm{Mg}$ because of a much reduced runoff. With much-reduced runoff, $\mathrm{Mg}^{2+}$ and $\mathrm{Ca}^{2+}$ are far less concentrated, while $\mathrm{SO}_{4}{ }^{2-}$ is reduced and removed as iron sulfide. Phosphate (too dilute to be shown) is extremely low.

Figure 4. Effect of temperature on $\left[\mathrm{M}^{n+}\right] /\left[\mathrm{H}^{+}\right]^{n}$ ratios in hydrothermal fluids. Increased acidity of the fluids at high temperature overwhelms the effect of temperature on equilibrium constants. Equations established on Iceland geothermal fields and taken from Arnorsson et al. (1983). These equations incorporate the effect of ionic strength. Water-rock temper- 
ature interaction (weathering) at low temperatures is a proton sink in contrast to hightemperature processes which produce low-pH solutions.

Figure 5. Effect of chlorine on the composition of solutions calculated from Arnorsson et al.'s (1983) equations. Units in mol $\mathrm{L}^{-1}(\mathrm{M})$. This plot illustrates the potential of using hydrothermal fluid reconstructions and ratios of heterovalent cations to infer the chlorinity of ancient seawater.

Figure 6. The $\mathrm{CH}_{4} / \mathrm{CO}_{2}$ ratio of the atmosphere in equilibrium with magnetite and $\mathrm{Fe}^{2+}$ for different oceanic values of $\mathrm{Fe}^{2+}$ and $\mathrm{pH}$. Red lines represent constant $\left[\mathrm{Fe}^{2+}\right]$ values and blue lines constant $\mathrm{pH}$ values.

\section{Table captions}

Table 1. Upper panel: fraction $f_{\mathrm{LT}}$ of the low-temperature hydrothermal fraction of off-axis hydrothermal fluids and mass fluxes $\Phi$. The value $\mathrm{f}_{\mathrm{LT}}=0.4$ is consistent with Hasenclever et al.'s (2014) estimate. The modern runoff value of $3.7310^{16} \mathrm{~kg} \mathrm{a}^{-1}$ was taken from (Wu et al., 2016). The flux of Ca carbonates of $4.010^{12} \mathrm{~kg} \mathrm{a}^{-1}$ was taken from (Mackenzie and Morse, 1992) and the adopted calcite/dolomite molar ratio of 3.5 is consistent with Milliman's (1993) estimates. A $\Phi_{\mathrm{H}}$ value of $1.010^{14} \mathrm{~kg} \mathrm{a}-1$ (total hydrothermal water flux) is consistent with Hasenclever et al.'s (2014) estimate for 40,000 km of fast-spreading ridges similar to the East Pacific Rise and with Palmer and Edmond's (1989) estimate from Sr isotopes. Lower panel, inputs (first three columns): concentrations of high- and low-temperature hydrothermal solutions. The $21^{\circ} \mathrm{N}$ site on the East Pacific Rise (Von Damm, 1990b) is representative of the high-temperature component because its $\mathrm{Cl}$ content indicates little liquid-vapor separation. Likewise, fluids from hole 504B, ODP leg 137 extrapolated at $\mathrm{Mg}=0$ (Magenheim et al., 1995) can be chosen as the low-temperature end-member. Lower panel, outputs: runoff values from Berner and Berner (2012) and sedimentary carbonate composition (ch) from 
Mackenzie and Morse (1992). The last two columns compare the calculated and measured seawater compositions. 


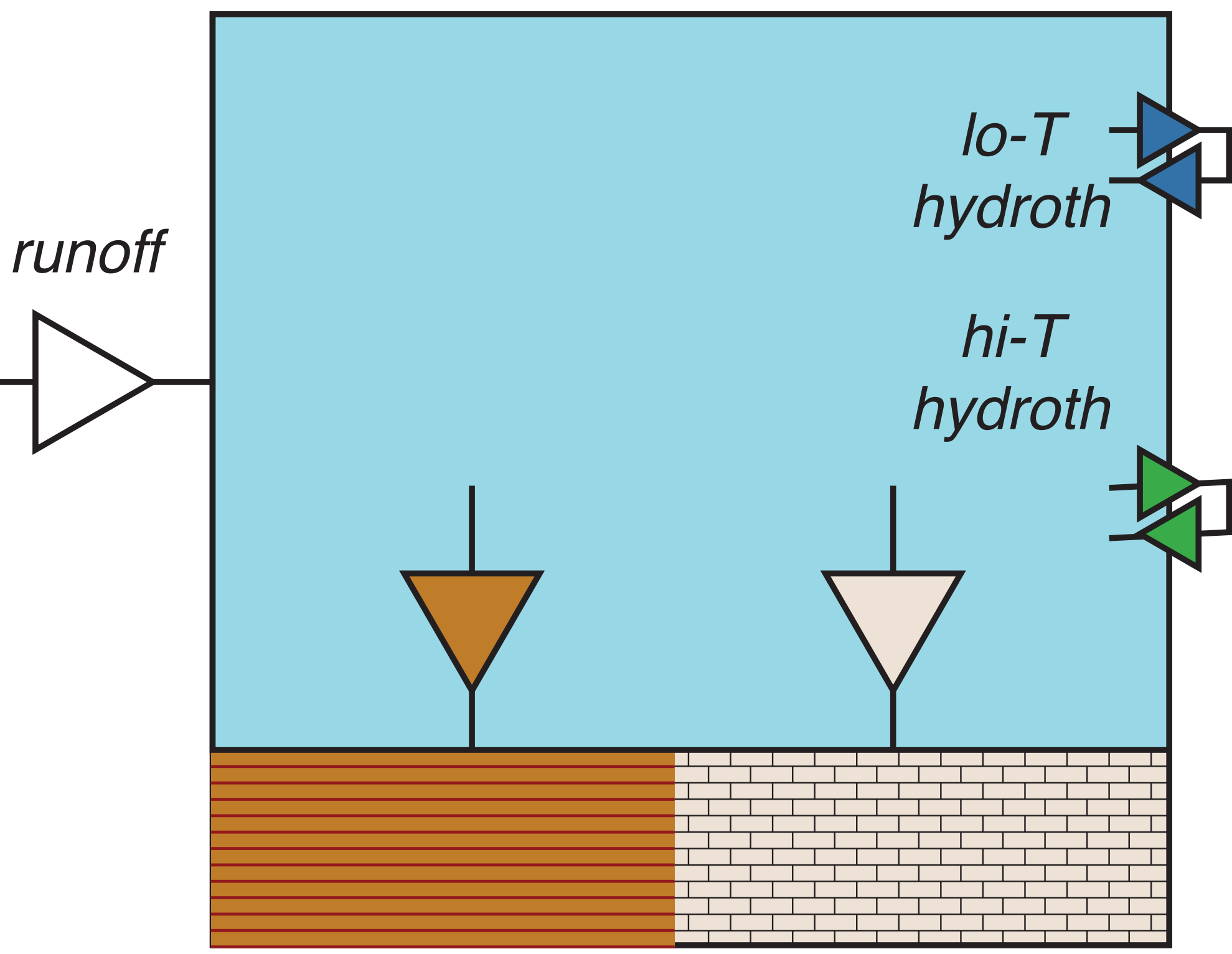
iron formations CaMg-carbonates 
Percent $P$ in sediments

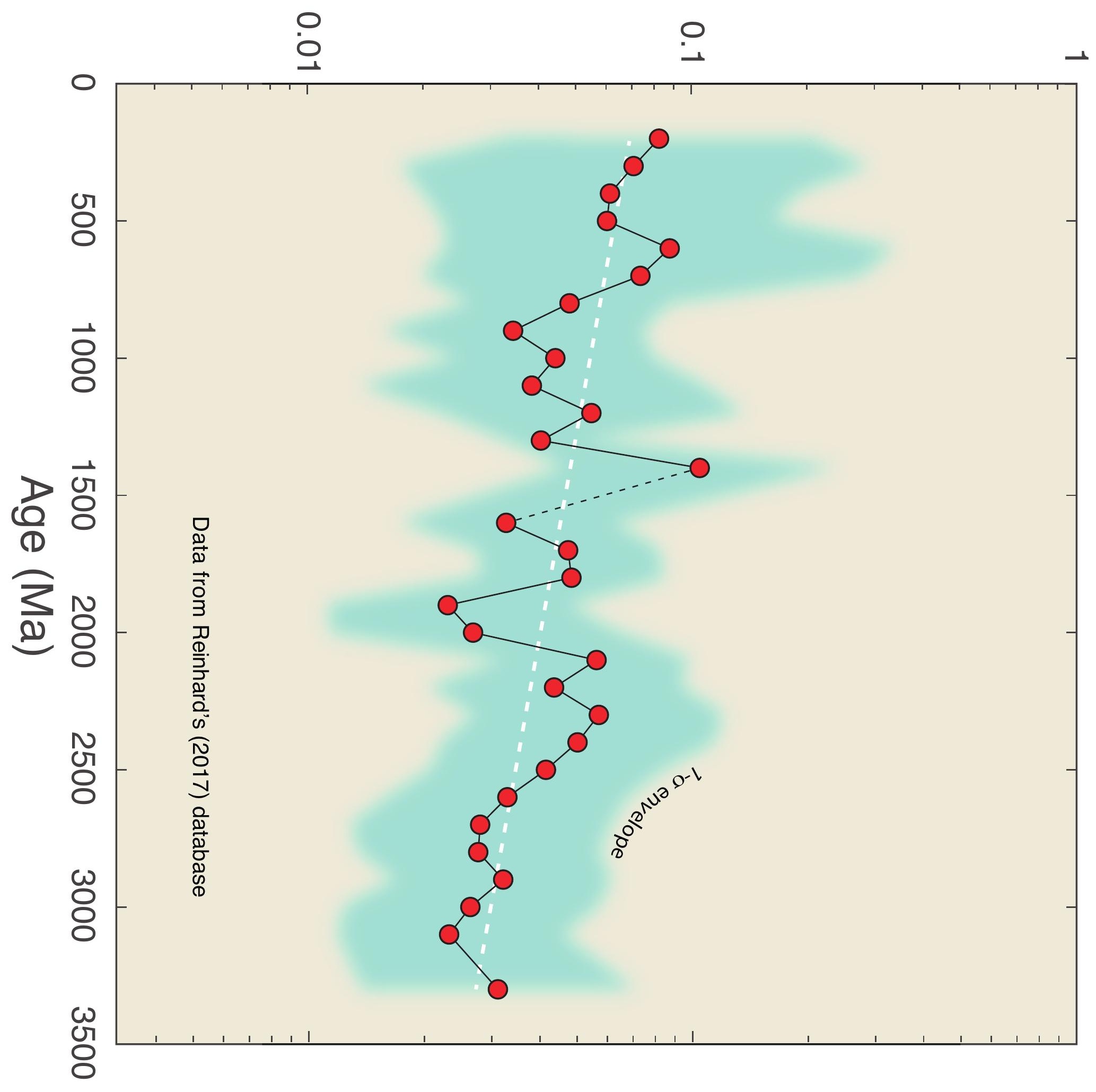


Figure 4

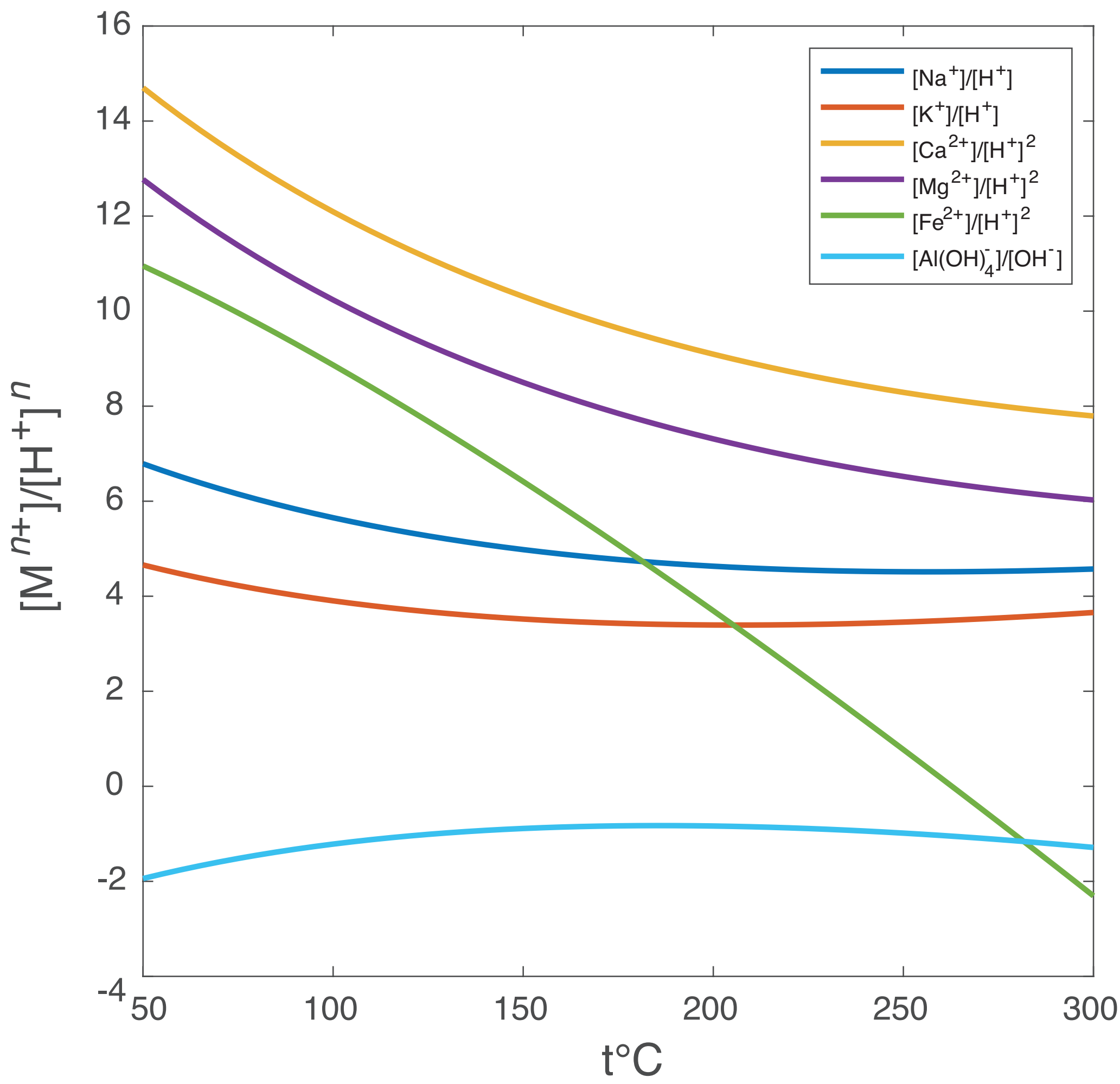


Figure 5
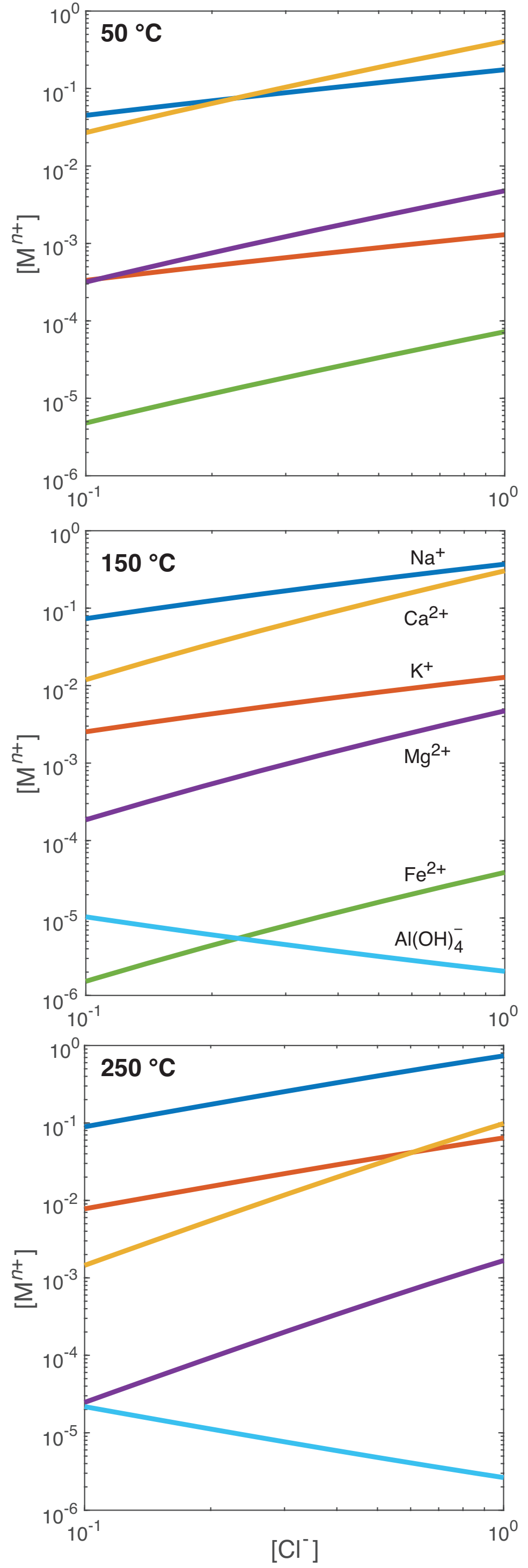
Figure 6

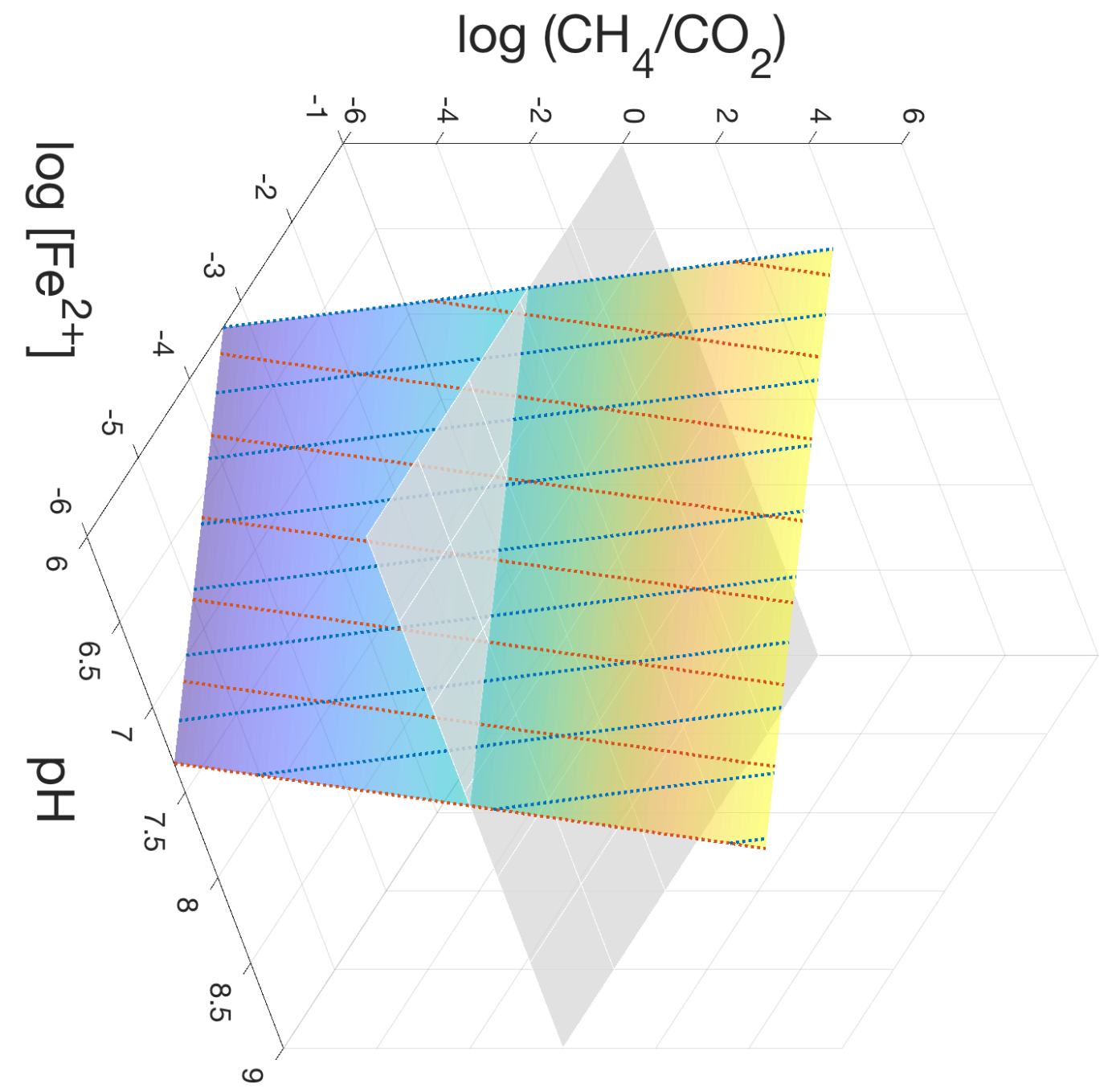


Table 1.

\begin{tabular}{|c|c|c|c|c|c|c|}
\hline \multirow[b]{3}{*}{ factor } & $f_{L T}$ & $\Phi_{H}$ & \multirow{2}{*}{$\frac{\Phi_{\text {riv }}}{3.7310^{16}}$} & $\Phi_{c h}$ & & \\
\hline & 0.4 & $1.0010^{14}$ & & $4.010^{12}$ & & \\
\hline & 1 & 1 & 1.094 & 0.3945 & & \\
\hline gat/kg & $C_{H T}^{i}$ & $C_{L T}^{i}$ & $C_{\text {riv }}^{i}$ & $C_{c h}^{i}$ & $C_{S w}^{i}$ calc & $C_{s w}^{i}$ meas \\
\hline Alk & 0 & 0 & 0.001 & 25.7 & 0.0023 & 0.0024 \\
\hline $\mathrm{Ca}^{2+}$ & 0.0156 & 0.0102 & 0.00038 & 10 & 0.011 & 0.01 \\
\hline $\mathrm{Mg}^{2+}$ & 0 & 0 & 0.00014 & 2.9 & 0.011 & 0.01 \\
\hline $\mathrm{Na}^{+}$ & 0.432 & 0.336 & 0.00026 & 0 & 0.5 & 0.48 \\
\hline $\mathrm{Sr}^{2+}$ & $8.1010^{-5}$ & $9.7010^{-5}$ & $8.9010^{-7}$ & $2.2910^{-2}$ & $8.9910^{-5}$ & $8.6010^{-5}$ \\
\hline $\mathrm{K}^{+}$ & 0.0232 & 0.00625 & $3.2510^{-5}$ & 0 & 0.0297 & 0.0104 \\
\hline $\mathrm{Rb}^{+}$ & $2.8010^{-5}$ & $1.0710^{-6}$ & 0 & 0 & $1.7210^{-5}$ & $1.3010^{-6}$ \\
\hline $\mathrm{Li}^{+}$ & $8.9110^{-4}$ & $7.3010^{-5}$ & 0 & 0 & $5.6410^{-4}$ & $2.6010^{-5}$ \\
\hline
\end{tabular}




\section{Declaration of interests}

$\bigotimes$ The authors declare that they have no known competing financial interests or personal relationships that could have appeared to influence the work reported in this paper.

$\square$ The authors declare the following financial interests/personal relationships which may be considered as potential competing interests:

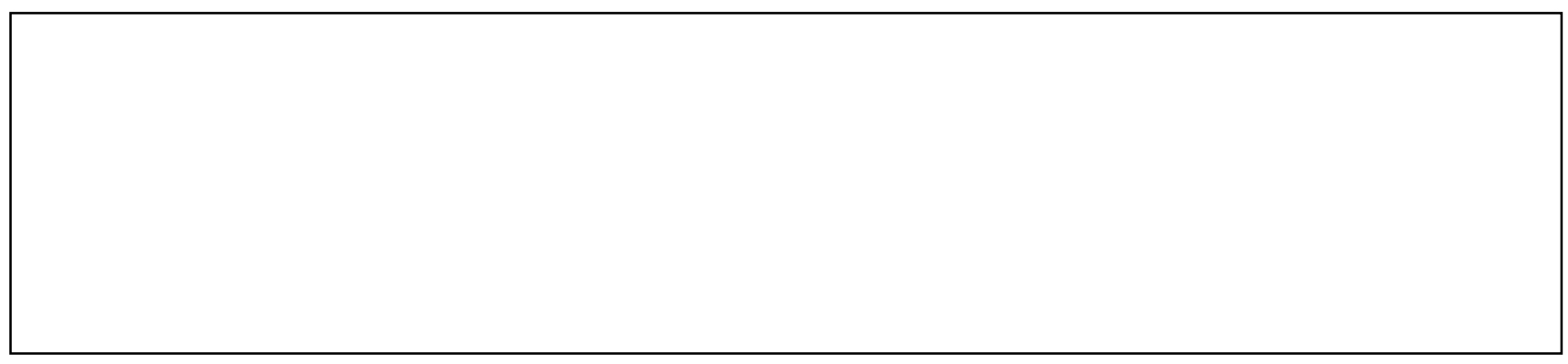

